$$
\begin{array}{ll}
\text { Han } & \\
\text { JAN }=0099 & \text { UCRL }-15988
\end{array}
$$

\title{
The Eifects of Chronic Radiation on Reproductive Success of the Polychaete Horm Neanthes arenaceodentata
}

Florence L. Harrison and

Susan L. Anderson

This paper was prepared for the

Office of Radiation Programs

U.S. Environmental Protection Agency

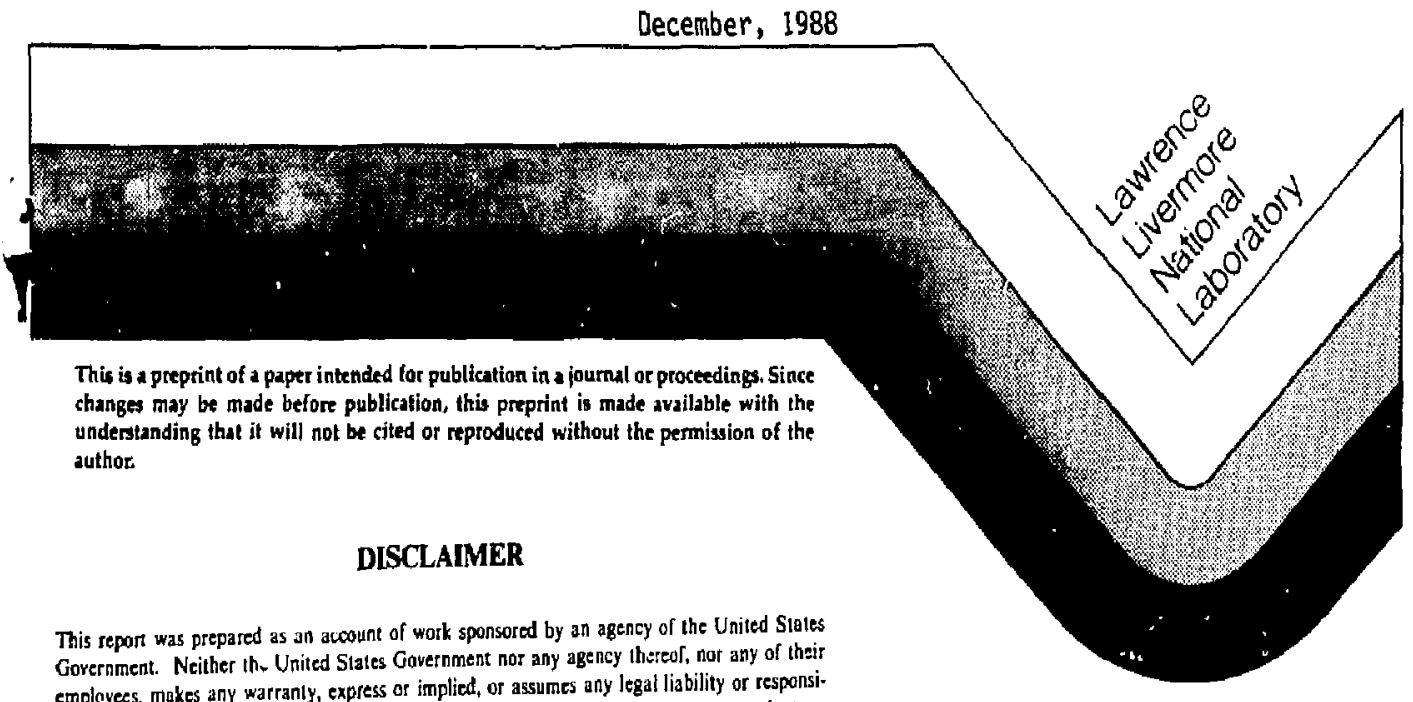
employees, makes any warranly, express or implied, or assumes any legal liability or responsibility for the accuracy, completeness, or useiulness of any information, apparatus, producl, of process disclosed, or represents that its use would not infringe privately owned rights. Reference herein to any specific commercial product, process, ot service by trade name, trademark. inanulacturet, or otherwise does not necessafily constitute or imply its endorsement, recommendalion, or favoring by the United Siales Government or any agency thereof. The views and opinions of authors expressed herein do not necessarily state or reffect those of the United States Government or any agency thereof. 


\section{DISCI.HINER}

This docussenl was plepated as an arenunt nf wark sponenrtid by an ugenc; of the I nited Sintes Goverament. Neither the C'niled States Cinernment nor the C'nikersily

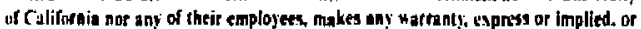
assumes ang legal lisbility or responsibilify for the atcurary. compterenesh of usefulness of ans information appaniox product, of process disclowed, of tepresents thal its use nould not infrinac pritalely an ned rights. Refectense bereia to uny specific commerciat pruducis. process or service by Irade name, trademurk manuracturar, or stheru ise, does nol necessurily constilute or imply its endorsement, recommendstion, or favoring by the Iniled States Gorernment of the L'niversity of Californin. The sites and opitions of authors expressed herein do not pecescarlity state or reflect those of the Lipited silats Goremment ar the L'aiver sity of Californith sand shall not be aid lof adertbing of producl endoryement perposes. 
THE EFFECTS OF CHRONIC RADIATION ON REPRODUCTIVE SUCCESS

OF THE POLYCHAETE WORM NEANTHES ARENACEODENTATA

\author{
Florence L. Harrison and Susan L. Anderson \\ Environmental Sciences Division \\ Lawrence Livermore National Laboratory \\ Livermore, CA 94550
}

\author{
Project Officer \\ Marilyn E. Varela \\ Report prepared for the \\ Office of Radiation Programs \\ U.S. Envi ronmental Protection Agency \\ Washington, DC 20460
}




\section{FORENORD}

In response to the mandate of Public Law 92-532, The Marine Protection, Research, and Sanctuaries Act of 1972, as amended, the Environmental Protection Agency (EPA) has developed a program to promulgate regulations and criteria to control the ocean disposal of low-level radioactive wastes. The EPA seeks to understand the mechanisms for biological response of marine organisms to the low levels of radioactivity that may arise from the release of these wastes as a result of ocean disposal practices. Such information will play an important role in determining the adequacy of envirommental assessments provided to the EPA in support of any disposal permit applications. Although the EPA requires packaging of low-level radioactive wastes to prevent release during radiodecay of the materials, some release of radioactive material into the deep-sea environment may occur if a package deteriorates. Therefore, methods for evaluating the impact on biota are being evaluated.

Mortality and phenotypic responses are not anticipated at the expected low environmental levels that might occur if radioactive materials were released from the low-ievel waste packages. Therefore, traditional bioassay systems are unsuitable for assessing sublethal effects on biota in the marine environment. The EPA Office of Radiation Programs has had an ongoing program to examine sublethal responses at the cellular level, using cytogenetic endpoints.

The present study examines the effects of chronic radiation on the reproductive success of the marine polychaete. Neanthes arenaceodentata, a low-fecund invertebrate species. Data were generated through the second fifial generation on brood size, abnormal adevelopment, and numbers of embryos living, dying, and dead following lifetime exposure to radiation.

The results of this research may be useful in evaluating ocean disposal of other materials because many other pollutants are also mutagenic. Cellular level endpoints and those indicative of reproductive success, and therefore predictive of population-level impacts, could ultimately be used to compare the risks of several pollutant classes.

The Agency invites all readers of this report to send any comments or suggestions to David E. Janes, Director, Analys is and Support Division, Office of Radiation Programs (ANR-461), U.S. Environmental Protection Agency, Washingtor, DC 20460.

\footnotetext{
Richard J. Guimond, Director

office of Radiation Programs (ANR-458)
} 
forckord.......................................

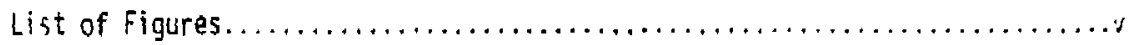

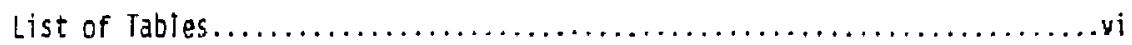

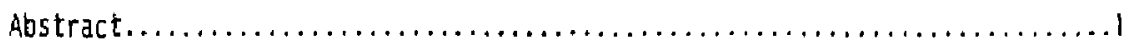

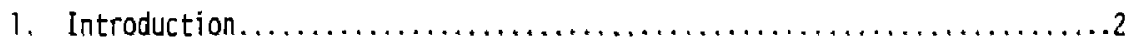

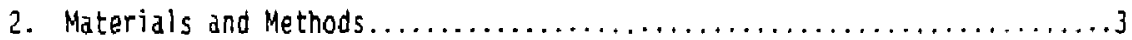

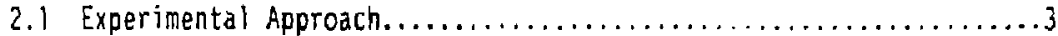

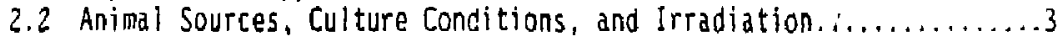

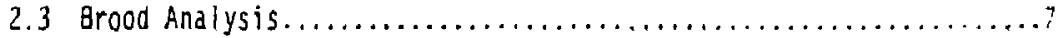

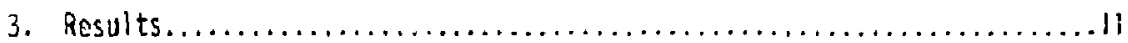

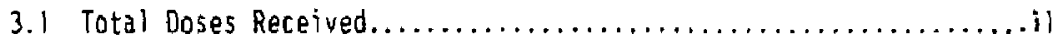

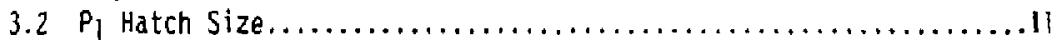

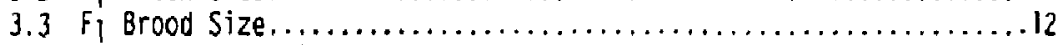

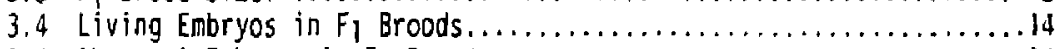

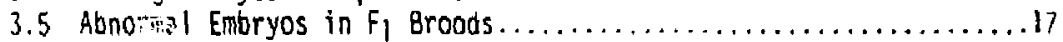

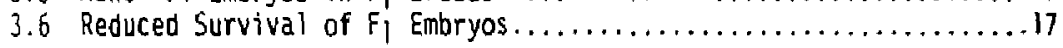

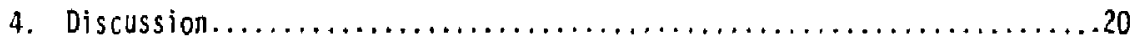

Acknowl edgments $\ldots \ldots \ldots \ldots \ldots \ldots \ldots \ldots \ldots \ldots \ldots \ldots \ldots \ldots \ldots \ldots \ldots \ldots \ldots$

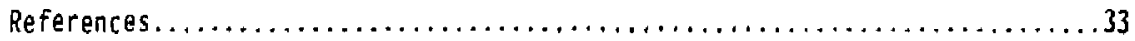

Appendix: Data Base from the Experiment to Determine the Effects of Chronic Radiation on Reproductive Suctess of Neanthes arenaceodentata $\ldots \ldots \ldots \ldots \ldots \ldots \ldots \ldots . \ldots \ldots$ 


\section{LIST OF FIGURES}

1. Summary of the life-history stages and of the steps in the procedure followed to determine the effects of chronic radiation on reproductive success of Neanthes arenaceodentata..........4

2. Schematic diagram of the radiation-exposure facility. The ${ }^{60}$ Co source and the control zone were shielded heavily with lead. .6

3. Embryo abnormalities identified in sacrificed broods. Normal clcavage pattern (a), atypical cleavage pattern (b), and embryos with void regions (c) are shown...

4. Broods subjected to a trypan-blue-exclusion test were differentiated into emoryos that were (a) alive (free of blue color), (b) dying (partially stained blue), and $(c)$ dead (totally stained blue)

5. The percent of broods from the $F$, mated pairs in each of four categories $(n \geq 75 \%, 75 \%, n \geq 50 \%, 50 \%) n \geq 25 \%$. and $n<25 \%$ ) of percent living embryos in the brood...............

6. The percent of broods from $F_{1}$ mated pairs in each of four categories $(n \geq 150,150>n \geq 100,100>n \geq 50$, and $n(50)$ of numbers of abnormal embryos in the brood.............

7. The percent of broods in each of four categories ( $n \geq 75 \%, 75 \%, n \geq 50 \%, 50 \%, n \geq 25 \%$, and $n<25 \%$ ) of percent abnorma embryos in the brood.

B. The percent of broods from the $F_{1}$ mated pairs in each of four categories $(n \geq 150,150, n \geq 100,100>n \geq 50$, and $n<50)$ of actual and estimated numbers of hatchi ings..........23

9. The percent of brools in each of four categories

$(n \geq 75 \%, 75 \%>n \geq 50 \%, 50 \%>n \geq 25 \%$, and $n<25 \%$ )

of percent survival to hatching of the embryos

in the brood.

10. Mean percent survival of embryos (expressed as percentage of the survival fraction of the controls) as a function of chronic dose. Data from broods that hatched or that were harvested before day 3 were excluded. 
1. Steps in the procedure used to harvest the broods from the $F_{1}$ mated pairs. The harvest was performed about 4 to $6 \mathrm{~d}$

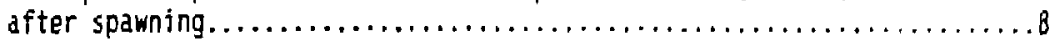

2. Mean radiation dose received by worms in each radiation-exposure group. The mean duration of the exposure is in parentheses..........12

3. Number of embryos from parental $\left(P_{1}\right)$ and first filial $\left(F_{1}\right)$ generations in control and radiation-exposed groups. The brood from the $F_{1}$ generation was sacrificed before hatching occurred........13

4. Number of embryos in broods from the control and radiation-exposed Fi mated pairs. The broods were sacrificed before hatching occurred and were assigned to one of four categories

$(n \geq 150,150>n \geq 100,100\rangle n \geq 50$, and $n\langle 50\rangle$, according to the number of embryos in the brood...

5. Results from the trypan-blue-exclusion test of the living, dying, and dead $\mathrm{F}_{2}$ embryos in the broods from the control and radiation-exposed $F_{1}$ mated pairs. The broods were sacrificed before hatching occurred and were assigned to one of four percentage categories $(n \geq 75 \%, 75 \%>n \geq 50 \%, 50 \%, n \geq 25 \%$, and $n(25 \%)$, according to the percent of living embryos in the brood.

6. Results from the analysis of the normai and abnormal embryos in the broods from the control and radiationexposed $F_{1}$ mated pairs. The broods were sacrificed before hatching occurred and were assigned to one of four categories ( $n \geq 150,150>n \geq 100,100>n \geq 50$, and $n<50$ ), according to the number of abnormal embryos in the brood.

7. Results from the analysis of normal and abnormal embryos in the broods from the control and radiation-exposed mated pairs. The broods were sacrificed before hatching occurred, the number of normal and abnormal embrycs detcrmined, the percent of abnormal embryos calculated, and then the broods were assigned to one of four categories ( $n \geq 75 \%$, $75 \%>n \geq 50 \%, 50 \%) n \geq 25 \%, n(25 \%)$. according to the percentage of abnormal embryos in the brood.

8. Results from the analysis of the numbers of $F_{2}$ embryos that actually hatched or were estimated to hatch from the broods of the control and radiation-exposed $F_{1}$ mated pairs. The broods were assigned to one of four categorie: $(n \geq 150$, $150>n \geq 100,100>n \geq 50$, and $n(50)$, according to the

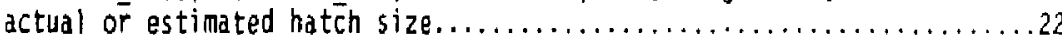


9. Results of the analysis of survival to hatching of embryos in the broods of the control and radiation-exposed $F_{1}$ mated pairs. The percent survival was calculated by dividing the estimated hatch size by the brood size, and then the broods were disigned to one of four categories $(n \geq 75 \%, 75 \%) n \geq 50 \%$, $502>n \geq 25 \%$, and $n<25 \%$ ), according to the percent of survival of the embryos.

10. Comparison of the effects of acute and chronic irradiation on Neanthes arenaceadentata. The values are percents of the broods in the category indicated................................29

11. Comparison of the effects on reproductive success of exposure of Neanthes arenaceodentata to different doses of contaminants.........31

A-1. Experimental data from Neanthes arenaceodentata $F$ mated pairs that were not irradiated with an external gamma-radiation source (controls). The number of days from spawn to hatch and from hatch to spawn as well as the estimated hatch size are provided.......................................

A-2. Experimental data from Neanthes arenaceodentata $F_{1}$ mated pairs that were exposed to $0 . \overline{19 \mathrm{mG} / \mathrm{h}}$ from an external gamma-radiation source. The number of days from spawn to hatch and from hatch to spawn as well as the estimated hatch size are provided.

A-3. Experimental data from Neanthes arenaceodentata $F_{1}$ mated pairs that wer e exposed to $2 . \overline{\mathrm{mCy} / \mathrm{h}}$ from an external gamma-radiation source. The number of days from spawn to hatch and from inatch to spawn as well as the estimated hatch size are provided...

A-4. Experimental data from Neanthes arenaceodentata $F_{1}$ mated pairs that were exposed to $17 \mathrm{mG} / \mathrm{h}$ from an external gama-radiation source. The number of days from spawn to hatch and from hatch to spawn as well as the estimated hatch size are provided... 
The effects of lifetime exposure to chronic irradiation on reproductive success were assessed for laboratory populations of the polychaete worm Neanthes arenaceodentata. Lifetime exposure was initiated upon the spawning of the $P_{1}$ female and was terminated upon spawning of the $F_{1}$ female. Groups of experimental worms received either no radiation (controls) or $0.19,2.1$, or $17 \mathrm{mig} / \mathrm{h}$. The total dose received by the worms was either background or approximately $0.55,6.5$, or 54 Gy, respectively. The broods from the $F_{1}$ inated pairs were sacrificed before hatching occurred, and information was obtained on brood size, on the number of normal and abnormal embrvos, and on the number of embryos that were living, dying, and dead.

The mean number of embryos in the broods from the $f_{1}$ females exposed to lifetime radiation of 0.19 and $2.1 \mathrm{mGy} / \mathrm{h}$ was not significantly different from the mean number of embryos from control females; however, the mean number of embryos was different from those $F_{1}$ females exposed to $17 \mathrm{mG} / \mathrm{h}$. There was a significant reduction in the number of live embryns in the broods from the $F_{1}$ mated pairs that were exposed to the lowest dose rate given, $0.19 \mathrm{mGy} / \mathrm{h}$, as well as those exposed to 2.1 and $17 \mathrm{mGy} / \mathrm{h}$. Also, increased percentages of abnormal embryos were determined in the broods of all the radiation-exposed groups.

Our results on embryo abnormalities and mortalities indicate that dominant-lethal mistions, and possibly recessive-lethal mutations, were most likely induced in the germ cells and that these mutations had an adverse effect on reproductive success by affecting the survival of edrly life stages. Except for those mated pairs exposed to $17 \mathrm{mGy} / \mathrm{h}$, there was no evidence of gamete killing, nor was there evidence of reduced fertilization success because the number of developing embryos in the broods did not decrease with increased dose. From our data on estimated hatch size and actual hatch size, we concluded that doses as iow as $0.19 \mathrm{mG} / \mathrm{h}$ can reduce significantly the size of hatches when lifetime doses are given. 


\section{INTRODUCTION}

One of the problems facing managers and scientists concerned with the impact of contaminants on aquatic environments is assessment of the effects of chronic exposure to sublethal levels of potentially toxic materials. One special concern is the response of aquatic organisms to long-term exposure to direct-and indirect-acting mutagens; exposure to mutagens can result in alterations in genetic material in both somatic and germ cells (UNSCEAR, 1986). Important detrimental effects of mutagens in somatic cells are the induction of tumors and cancer. Importarit detrimental effects on germ cells are the induction of dominant- and recessive-lethal mutations, cell killing, and the development of abnormalities in early life-history stages, all of which are factors that affect reproductive success. Becal'se preservation of the health of aquatic environments requires insuring the maintenance of indigenous populations as well as the survival of individuals, managers of aquatic resources are concerned about the impacts of contaminants on reproductive success.

A direct-acting mutagen for which there is considerable data is ionizing radiation (NRC 1980; UNSCEAR 1977, 1982, 1986). Ionizing radiation is a genotoxic agent for which the dose to aquatic animals can be determined accurately without parallel studies on chemical metabolism. Ionizing radiation is an ideal model mutagen because the nature of the damage and the processes that modify the lesions are well characterized. Data on the effects of radiation on aquatic organisms have been reviewed extensively (Polikarpov 1956; Templeton et al. 1971; Templeton 1976; Chipman 1972; Ophel 1976; 8laylock and Trabalka 1978; Egami and Ijiri 1979; Woodhead 1984; Anderson and Harrison 1986). However, the great preponderance of the data is on acute rather than shronic effects.

The extensive data on the effects of acute radiation on mortality rates in aquatic animals appear to iridicate that the radiosensitivity increases with biological complexity, i.e., that the higher the phylogenetir position, the lower the LO50 (Templeton 1976; Blaylock and Trabalka 19;5; Woodhead 1984). However, the limited data on effects of acute radiation at the celluiar level indicate that this conclusion may not be valid. Induction of chromosomal aberrations and sister chromatid exchanges by acute radiation in the polychaete Neanthes arenaceodentata occurred at doses that did not differ greatly from doses inducing such responses in some mammals (Harrison et al. 1986; Anderson et al. 1987). Furthermore, some fishes and invertebrates are as sensitive to radiation as some mammals (Rackham and Woodhead 1984; Harricon and Anderson 1988; UNSCEAR 1986), although the data on the effacts of radiation on reproductive success indicate that there is considerable variation among species (see reviews of Woodhead 1984; Anderson and Harrison 1986).

The impact of radiation on the reproductive success of an aquatic organism may be related not only to the sensitivity of its gametes but also to its reproductive strategy. In a highly fecund species, the survival of early life stages may be less than $1 \%$, and the loss of abnormal embryos induced from radiation expcsure may be masked completely by those lost from density-dependent factors, such as food limitation and predation. It might be expected that the impact of radiation exposure to a species of low fecundity may be considerable because recruitment is more closely related to parent stock size. The limited data available on the use of sealed sources for the 
chronic exposure of fish are not sufficient to allow conclusions to be drawn. Hoodhead (1977) found raduced fecundity in the guppy (a low-fecundity species, from a lifetime exposure to about $1.7 \mathrm{mGy} / \mathrm{h}$, while Welander et al. (1948) noted some long-term delete:ious effects in salmon (a high-fecundity species) at about $2 . i \mathrm{imG} / \mathrm{h}$.

The objectiun of this study wids to obtain information on the effects of chrinic radiation ch the reproductive success of a relativeiy low-fecundity invertebrate marine animal. The species selected was Neanthes arenaceudentata, which is a polychaete worin that is avajlable cominercially, is adsily maintained in the laboratory, and for which considerable information is avalishle on effects from acuie radiation (Harrison et al. 1986; Anderson et al. 987; Ha.rison and Anderson 1988) and from toxic inorganic and organic contaminants (Rossi and Anderson 1978; Oshida et al. 1981; Oshida and Ward, 1982). The data obtsined from tris study on effects of chronic exposure to the direct-acting mutagen, radiation, should be useful in evaluating ocean disposal of radioactive materials as well as other mutagens. Also, comparison of data for worms exposed chronically to data for worms exposed acutely will provide information on the importance of total dose and dose rate on response to radiation.

\section{MATERIALS AND METHOOS}

\section{2.i Experimental Azproach}

The effect of chronic lifetime radiation on the reproductive success of N. arenaceodentata was determined by making observations on control and radiation-exposed worms. Data were obtained on the parental $\left(P_{1}\right)$, first filial $\left(F_{1}\right)$, and second filial $\left(F_{2}\right)$ generations. Lifetime exposure to radiation was initiated upon the spawning of the $P_{1}$ female. At that time, these eritoryos, which weir being cared for by the male, were placed in front of a radiation source. The lifetime exposure was terminated upon the spawning of

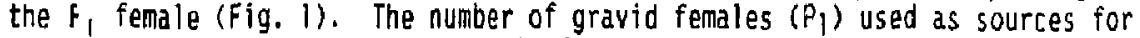
embryos for the control group was 6 , for those receiving 0.19 and $2.1 \mathrm{mG} / \mathrm{h}$ was 7. and for those receiving $17 \mathrm{mGy} / \mathrm{h}$ was 3 . The total number of troods analyzed for the control group was 94 , for the group receiving $0.19 \mathrm{mGy} / \mathrm{h}$ was 84, for the group receiving $2.1 \mathrm{mGy} / \mathrm{h}$ was 80 , and for the group receiving 17 $m G y / h$ was 59. Numbers of offspring of the $P_{1}$ and $F_{1}$ generations were determined as well as the times of spawning, hatching, and exiting of larvae from the parental tube. In addition, for boin control and radiation-exposed $F_{1}$ mated pairs, the embryos in the bruod were examined for abnormalities and subjected to a dye-exclusion test to determine the number that were living, dying, and dead. Data accumulated on the brood from each $F_{1}$ mated pair are provided in the Appendix.

\section{Animal Sources, culture Conditions, and Irradiation}

Worms used in the experiment were obtained either from Or. Donald Reish (California State University, Long Beach, CA) or from Brezina ard Ac Jciates (Dillion Beach, CA). After the adult worms were received from the sucpiliers. they were held in 80-L aquaria for several weeks. Once the female worms began to develop oocytes, they were rentoved from the aquaria, mated with vigorous inales from the same supplier, and cultured according to procedures by Reish (1934). Docytes in the coelom of N. arenaceodentata are clearly discernable because the cuticle is translucent. Each mated pair $\left(P_{1}\right)$ was placed in a 


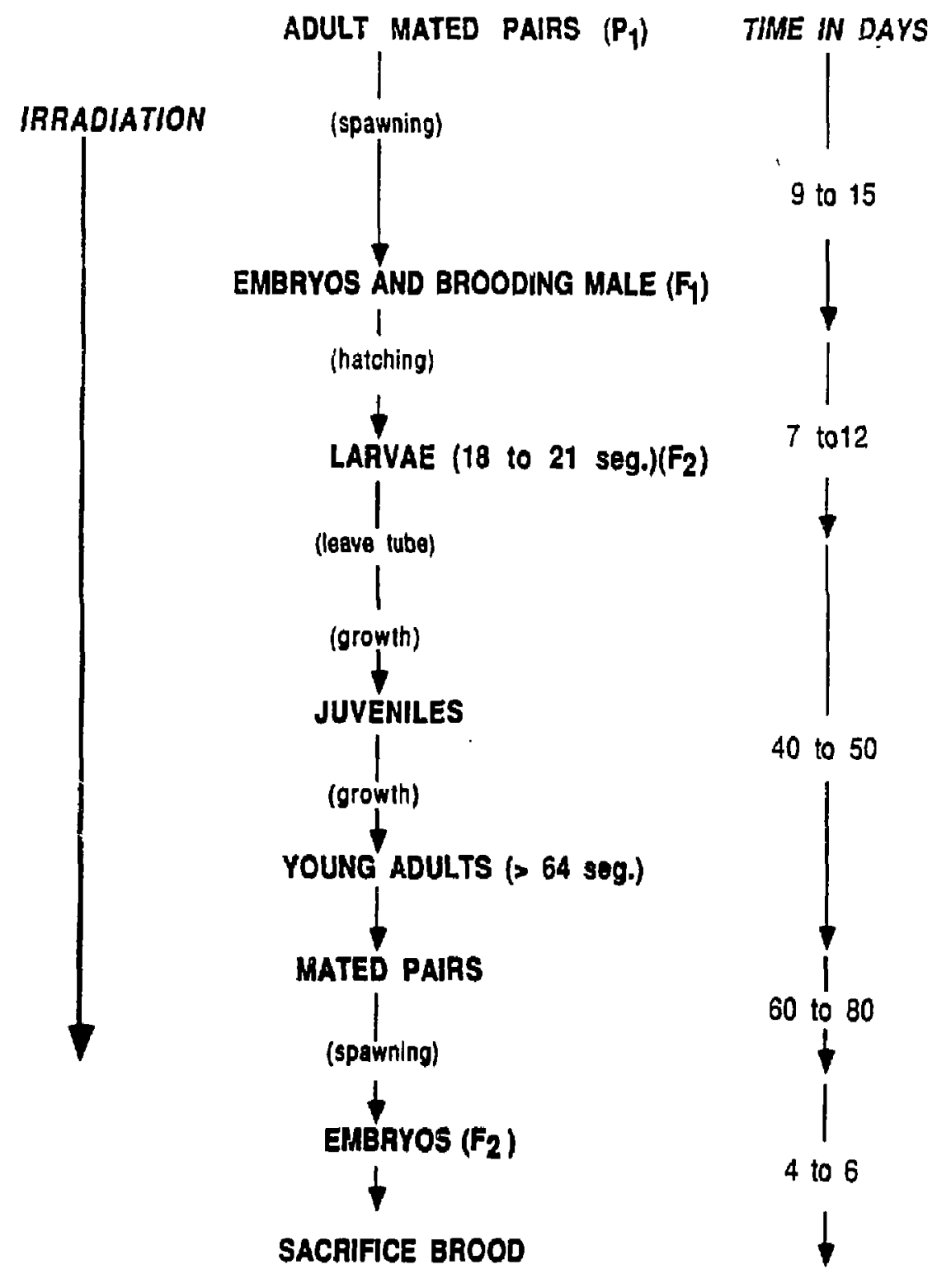

Figure 1. Summary of the life-history stages and of the steps in the procedure followed to determine the effects of radiation on reproductive success of Neanthes arenaceodentata. 
large plastic petri dish (120-mm diameter $\times 20-m m$ depth) containing about $80 \mathrm{~mL}$ of filtered (1.0- $\mu \mathrm{m}$ pore size) seawater; tube formation occurred within the next $24 \mathrm{~h}$. Seawater used in the experiments was pumped from the Pacific Ocean and passed through sand filters at the University of California Bradega Marine Laboratory before it was transported to the Lawrence Livermore National Laboratory; the seawater was stored before use in an underground $40,000-\mathrm{L}$ tank.

During the acclimation period. observations of the mated pairs were made $\therefore$ reekiy. At these times, most of the seawater in the dishes was aecaicad, the tubas were carefully trimined, excess mucus and fecal materiai were removed by wioing out the dish except in the cube area, newly filtered seawater was added, and fresh food was supplied (rehydrated freeze-dried Enteromorpha $5 \mathrm{p}$.$) . When the female stopped eating, which occurred when her$ coelom was filled with oocytes, the mated pair was transferred to the control area of the radiation facility and was observed daily to determine the day of spawning.

Irradiation of the embryos was initiated immediately after spawning occurred. The date of spawning was recorded, the female, who dies after spawning, was removeo from the petri dish (if she nad not been eaten by the male), and the petri dish containing the brooding male and the embryos was placed randomly in standard coimercial petri-dish racks that held 18 petri dishes (two stacks each of 9 petri dishes). The radiation delivered was from a 60 Co source (about $2.5 \times 10^{10} \mathrm{~Bq} ; 0.7 \mathrm{Ci}$ ). The racks were located in one of following four areas in the radiation facility: behind the radiation source in a lead-shielded site (control area) or at one of three sites increasingly distant from the radiation source (irradiation areas) (Fig. 2). The three distances from the source were chosen in adyance 50 that the worms in the petri dishes would be dosed at a rate of either approximately $0.21,2.1$, or 6) $\mathrm{mG} / \mathrm{h}$ (about $0.5,5.0$, or $50 \mathrm{rad} / \mathrm{d}$ ). However, actual dose rates delivered were $0.19 \pm 0.03,2.1 \pm 0.4$, and $17 \pm 1.1 \mathrm{mGy} / \mathrm{h}$. Because the area in front of the source from which a dose rate of $17 \mathrm{mGy} / \mathrm{h}$ could be delivered was limited, the number of broods exposed at this dose rate was smaller than those at the two lower dose rates. The temperature in the exposure facility was $20 \pm 2^{\circ} \mathrm{C}$. and the light level was low during the day, except during the maintenance periods.

Doses delivered to the worms were monitored using thermoluminescent dosimeters. These were sealed in plastic and placed in the seawater in the petri distes at positions similar to those occupied by the worms. Sets of dosimeters were used at each of the three distances from the scurce and were added at different times during the experiment. From the knowledge of the radiation exposure obtained from the dosimeters, of the number of days each worm was exposed to the source, and of the total time the radiation source was down during maintenance and feeding of the worms, the total lifetime dose received by each worm was calculated.

The broods were observed twice weekly, and care was taken to minimize anv disturbance of the brood: the seawater was not chaiged unless it appeared tc be becoming stagnant. The amount of food given was reduced and was placed at the opening of the tube. The date of hathning of the larvae, which occurred generally between 12 and 15 o after the spawning, was noted as well as the date that the larvae left the tube, which occurred between 7 and $12 \mathrm{~d}$ after the time of hatching. 


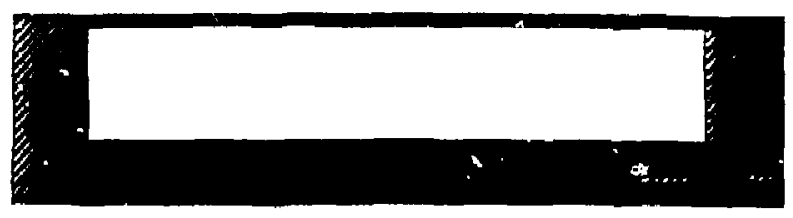

Control Area

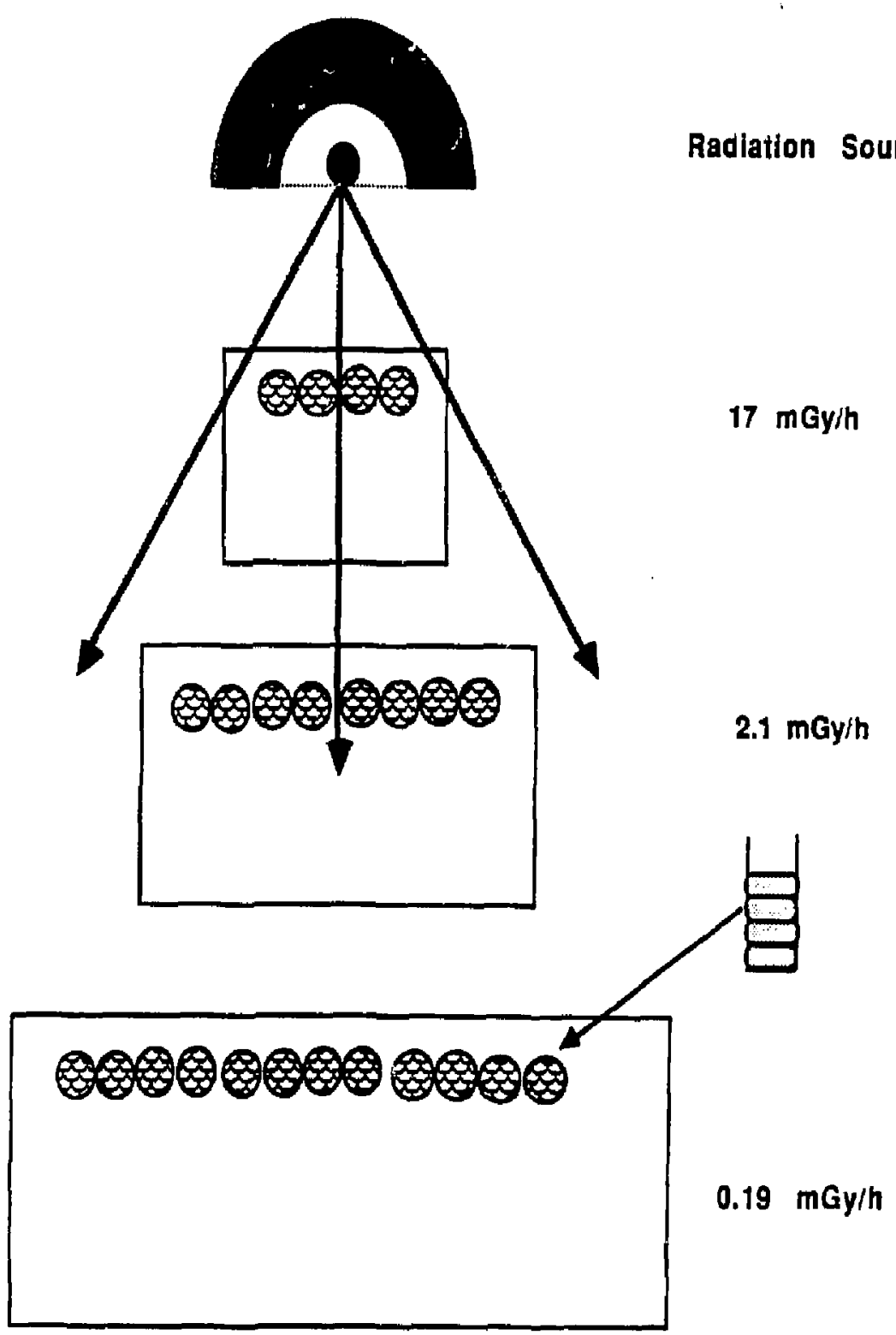

Figure 2. Schematic diagram of the radiation-exposure facility. The ${ }^{60} \mathrm{Co}_{0}$ source and the control zone were shielded heavily with lead. 
When most of the larvae in the brood left the tube (larvae had from 40 :70 segments), the larvae were removed from the large petri dish and triree larvae, each from the same brood, were placed in a small petri dish (60-mm diameter $\times 20$-fim depth) containing 10 to $15 \mathrm{~mL}$ of filtered seawater. Each small petri dish, containing three larvae, was placed in a standard commercial petri-dish rack in the same experimental area as the large one from which the larvae were obtained. Each rack held 64 petri dishes ( 8 stacks each of 8 petri dishes). Seawater in the small patri dishes was changed twice weekly, and the juveniles were fed dry, ground alfalfa that was less than $0.5 \mathrm{~mm}$ in diameter. The juveniles were fed immediately after the water exchange or more frequently if they required additional food. Considerable cannibalism occur-ad among the three juveniles in the same petri dish. in most petri dishes, only one worm survived to the juvenile stage.

When most of the juveniles had grown into young adults, their sex was determined and the fomales paired to vigorous males from the same brood, if sufficient males were available. If sufficient males were not available, they were paired with other males from the same dose-rate-exposure group. Next, the mated pair (first filial generation, $F /$ ) was transferred to a large (120-mm diameter $\times$ 20-rtm depth) petri dish. The petri dish with the mated pair was placed in a petri-dish rack at the same distance from the radiation source as that of the juveniles and parent worms $\left(P_{1}\right)$ from which they were derived. To reduce differences in dosimetry, the petri dish containing the mated pai- was always rotated so that their tube was always at the front of the rack (closest to the radiation source).

Again, the mated pairs $\left(\boldsymbol{F}_{\}}\right)$were observed and cared for as described for their parents $\left(P_{1}\right)$. The date of spawning of the $F_{1}$ female was noted, the brood was removed from in front of the source and placed in the control area. and then the brood was sacrificed about 4 to 6 d after the spawning date. The brood was sacrificed at this time because the nurturing male consumes the dead embryos as part of taking care of the brood. Therefore, to obtain an indication of total number of embryos in the brood, the brood was sacrificed before the male had time to consume a significant number of dead embryos. In those cases when large numbers of embryos died early in development (before about $6 d$ ), the gut of the male was yellow from yolk. When this occurred, it was recorded so that an indication could be obtained of those broods where the number spawned was greater than the number that was reco-ded present at the time the brood was sacrificed. The total duration of the experiment was about 8 months.

\subsection{Brood Analysis}

The analysis of the brood consisted of (1) enumeration and examination of the embryos and (2) a trypan-blue-exclusion test (Table 1). The analys is of the brood was performed by one or two persons. For the first part of the andysis, the embryos were remned from the tube and transferred quantitatively from their petri dish to a counting chanber. which was a petri dish bottom (60-mm diameter $\times 20-\mathrm{mm}$ depth) that had been divided into quadrants. The counting chamber containing the embryos was placed on graph paper. and then the total number of embryos in the spawn was deternined by systematically counting the embryos in each quadrant; $6 X$ magnification was used. Next, the number of abnormal and normal embryos was evaluated at $12 X$ 
Table 1. Steps in the procedure used to harvest the broods from the $F_{1}$ matec pairs. The harvest was performed 4 to 6 d after spawning.

Part I. Enumeration and Examination.

1. Removal of developing emoryos from tube to counting chamber.

2. Counting of embryos to determine brood size.

3. Determination of the stage of development of the embryos and the number of normal and abnormal embryos.

Part II. Trypan-Blue-Exclusion Test

1. Treatment of brood with trypari blue to identify living, dying, and dead embryos.

2. Preservation of embryos.

3. Calculation of estimated hatch size.

magnification. The two types of abnormal embryos identified were those that were aberrant morphologically and those that had delayed development. The morphologically abnormal embryos had atypical cleavage patterns and/or void regions (Fig. 3); the delayed-development embryos were zygotes or at the 2- or 4-cell stage when the brood was harvested. In the case where the embryos had both types of abnormalities, this fact was noted. The stages that were quantified were the unfertilized egg, zygote, 2-cell, 4-cell, prehatch, and hatchling stages; these stages were identifiable with a minimum of ambiguity. The few unfertilized eggs detected were found in broods that were scattered throughout the tube.

The second part of the brood analysis was a trypan-blue-exciusion test that was developed in our laboratory. After the embryos were counted and examined, the seawater was decanted and sufficient $0.4 \%$ trypan-blue solution in seawater to cover the embryos was added. The embryos wer $i$ exposed to the trypan blue for 5 min, the excess trypan-blue solution was tnen decanted, and the embryos rinsed with filtered seawater until the excess blue dye was gone. The embryos were examined under $6 x$ magnification, and the number that were totally stained blue (dead), partially stained blue (dying), and free of blue dye (live) were recorded (Fig. 4). Because of the staining of the embryos, i: could not be ascertained readily whether the dead and dying embryos ivere normal or abnormal. Next, the seawater was decanted and $4 \%$ formalin added to preserve the embryos.

For each brood, the number of embryos that should hatch into iarvae was estimated using the oata on the total number of embryos compared to the number of abnormal embryos or the number of embryos that were dead or dying. In 


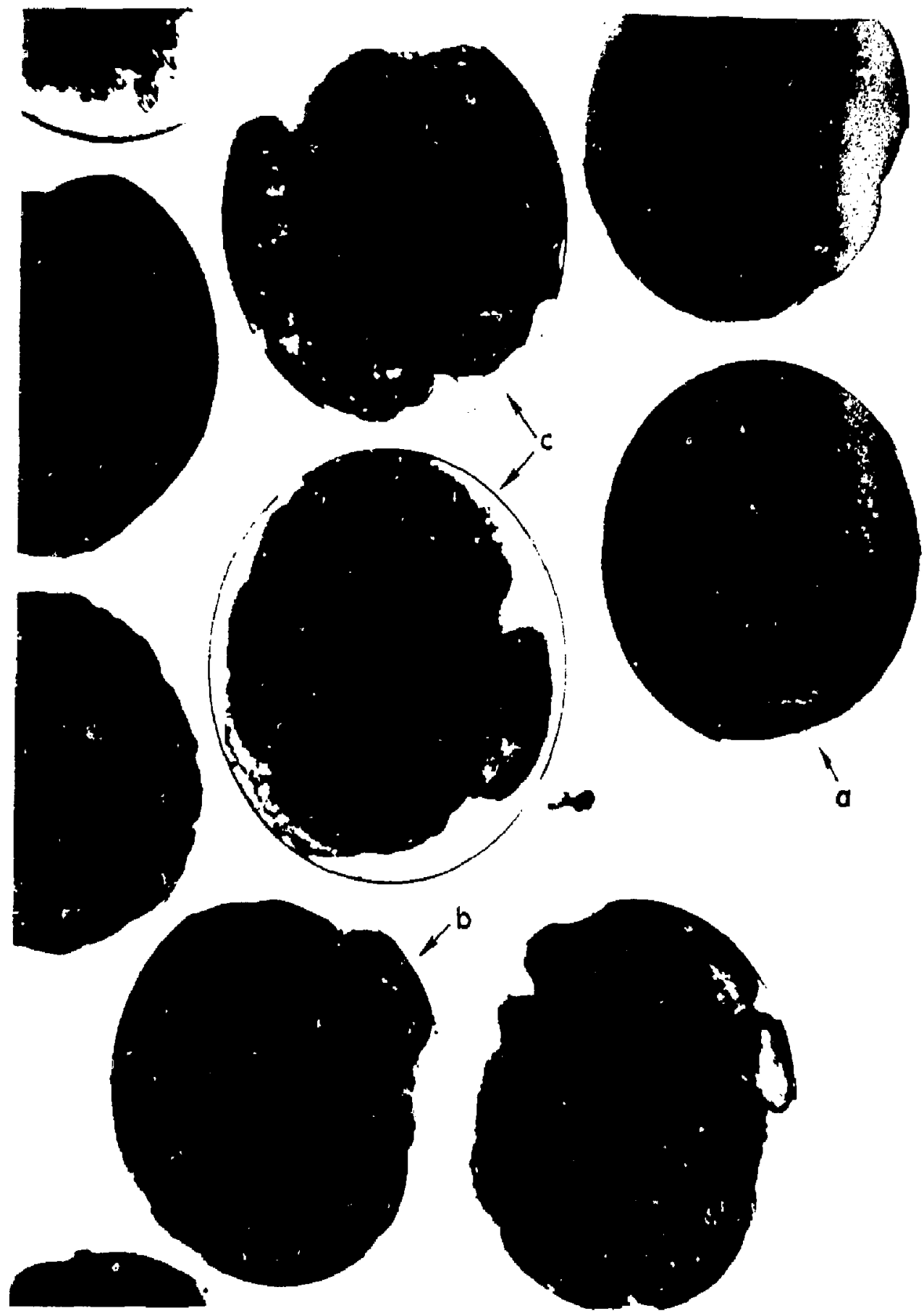

Figure 3. Embryo abnormalities identified in sacrificed broods. Normal cleavage pattern (a), atypical cleavage pattern (b), and embryos with void regions (c) are shown. 


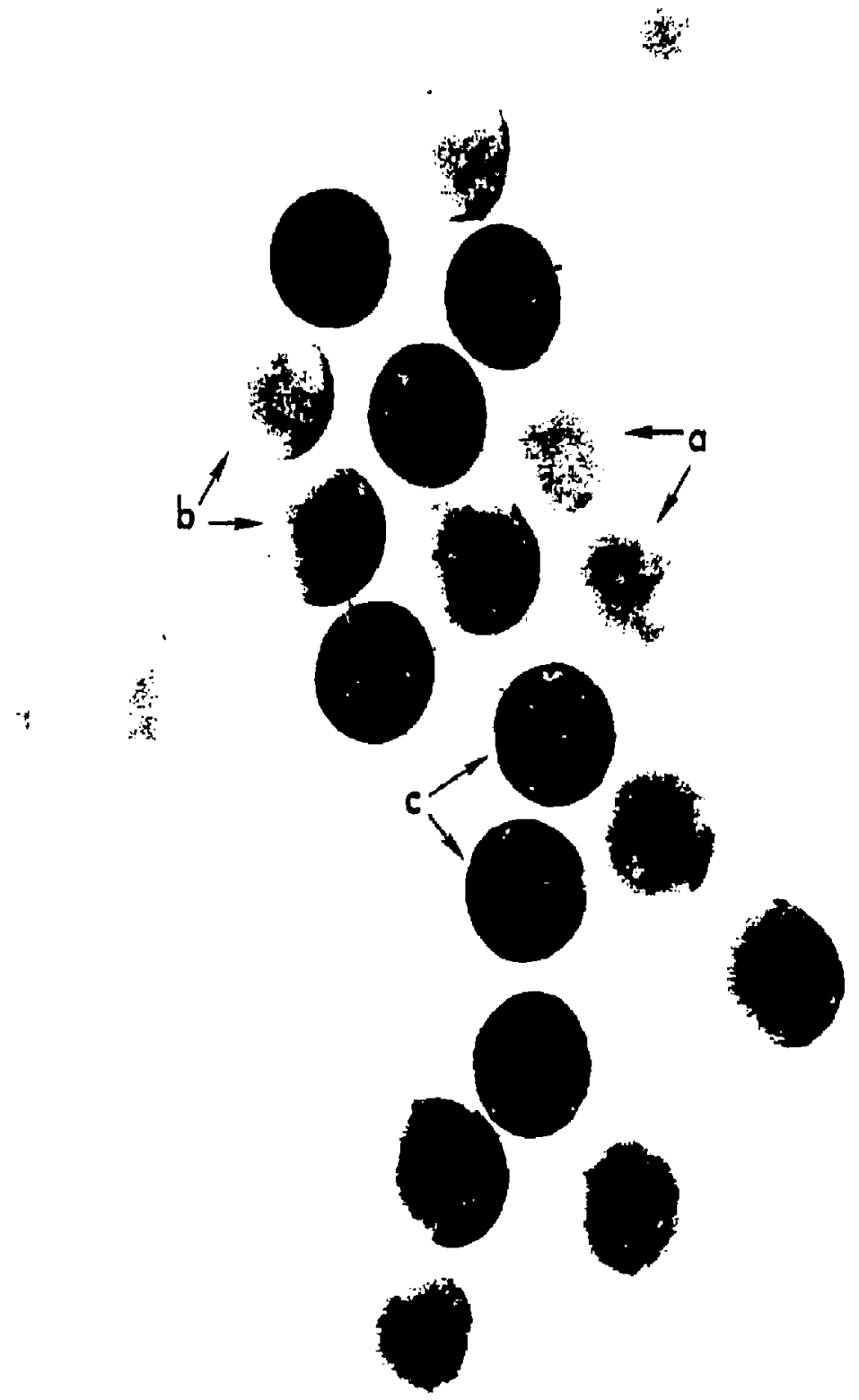

Figure 4. Broods subjected to a trypan-blue-exclusion test were differentiated into embryos that were (a) alive (free of blue color), (b) dying (partially stained blue), and (c) dead (totally stained blue). 
dimost all broods, the number of abnormal embryos was greater than the sum or the numbers of dead and dying embryos. The assumption made for thecalculation of the hatch size was that the abnormal embryos that were living would not survive to hatching but would die and be consumed by the brooding male. The estiluated hatch size (EHS) was calculaced from the following relationship:

EHS $=$ (Total numbers in brood) - (Total number of abnormals).

For example, if the total number of embryos in the brood was 400 and if 75 were abnormal, then

$$
\begin{aligned}
\text { EHS } & =400-75 \\
& =325 .
\end{aligned}
$$

In the few cases where tha number of dead and dying was greater than the number of abnormal embryos, the number of live embryos in the orood (the total number in brood minus number of dead and dying) was taken as the EHS.

Differences among control and radiation-exposed groups in brood size, in percentages of living embryos in the broods, in percentages of abnormal embryos in the broods, and in estimated and actual hatch size were analyzed using a Fest for Equal Proportions (Snedecor and Cochran 1967). Also, differences in brood size for the control and radiation-eyposure groups were examined using Analysis of Variance (ANOVA).

\section{RESULTS}

\subsection{Total Doses Received}

The approximate doses received by the experimental worms from the times (I) the eggs were spawned by the $P_{1}$ female until the larvae hatched and (II) the eggs were spawned by the $P_{1}$ female to the spawning of the $F_{1}$ female (normal lifespan for females) were determined (Table 2); the approximate total dose is the product of the mean duration of exposure and the mean dose rate. Because the experimental worms were shielded fren the radiation source during their maintenance, their mean duration of exposure was shorter than their lifetime. The developing $P_{1}$ embryos were exposed to radiation for an average of from 10 to $12 \mathrm{~d}$ and received total doses that ranged from 0.055 to $4.9 \mathrm{~Gy}$. The life-span dose received by the $F_{1}$ female worms ranged from 0.55 to 54 Gy.

\subsection{P Hatch Size}

We determined the number of embryos that hatched from each of the broods of the $P_{1}$ females (Table 3 ). The mean number of larvae that hatched from embryos exposed to each of the different dose rates was similar to the number of control embryos that hatched. Exposure to radiation did not appear to dffect the number of larvae that hatched from the $P_{1}$ broods. 
Table 2. Approximate total radiation doses received by worms in each radiation-exposure group. The mean duration of the exposure is in parentheses.

1. Py spawn to $F_{1}$ hatch

$\begin{array}{lll}\text { 1. } & 0.19 \mathrm{mG} / \mathrm{h}(12 \mathrm{~d}) & 0.055 \\ \text { 2. } 2.1 \mathrm{mG} / \mathrm{h}(10 \mathrm{~d}) & 0.50 \\ \text { 3. } 17 \mathrm{mG} / \mathrm{h}(12 \mathrm{~d}) & 4.9\end{array}$

II. Fl life-span dose
1. $0.19 \mathrm{mGy} / \mathrm{h}(120 \mathrm{~d})$
2. $2.1 \mathrm{mGy} / \mathrm{h}(128 \mathrm{~d})$
6.5
3. $17 \mathrm{mLy} / \mathrm{h}\langle 132 \mathrm{~d}\rangle$

\subsection{F, Brood Size}

The numbers of $F$ mated pairs that were placed in front of the source initially were sometimes greater than the numbers for which information was obtained; some worms were lost or killed accidentally during routine maintenance (Table 3). Information about the broods was obtained for only about half the $\mathrm{F}$, mated pairs exposed to the highest dose rate $(17 \mathrm{mG} / \mathrm{h})$ because some females resarbed their oocytes and then died (see the Appendix).

The mean $F_{1}$ brood size was always larger than the number that hatched from the $P_{1}$ female (Table 3). Because the brood from the $F_{7}$ females was sacrificed before hatching occurred and the brood from the $P$, female was allowed to proceed to hatching, it would be expected that the total number determined for the $F_{1}$ brood would be larger than the total number of hatchlings from the $P_{1}$ female. However, there were some broods from $F_{1}$ females as small as the number of larvae that hatched from the brood of the $P_{1}$ female.

We determined the mean size of the broods from the $F_{1}$ mated pairs that were obtained from each parental brood. In the control group, brood size ranged from 6 to 637 and had a normal distribution. Each brood was distributed into one of four categories $(n \geq 150,150>n \geq 100,100>n \geq 50$, and $\pi(50)$, according to the number of embryos in the brood (Table 4). A Test for Equal Proportions was used to determine which radiation-exposed groups had brood-size distributions that were significantly different from controls. The brood-size distribution was different only for the group of worms irradiated at a rate of $17 \mathrm{~ms} / \mathrm{h}$; the proporition of broods in the $n$ ) 150 category was lower than that of controls $(p<0.001)$. The overali mean brood size of the 0.19 and $2.1 \mathrm{mC} / h_{i}$ radiation-exposed groups did not differ 
Table 3. Number of embryos from parental ( $\left.P_{p}\right)$ and first fillial ( $\left.F_{l}\right)$ generations in control and radiation-exposed groups. The brood from the $F_{1}$ generation was sacrificed before hatching occurred.

\begin{tabular}{ccccc}
$\begin{array}{c}\text { P1 brood } \\
10\end{array}$ & $\begin{array}{c}\text { Parentai } \\
\text { hatch size }\end{array}$ & $\begin{array}{l}\text { Mated pairs } \\
\text { procedure }\end{array}$ & Filial brood size \\
\hline
\end{tabular}

A. Control

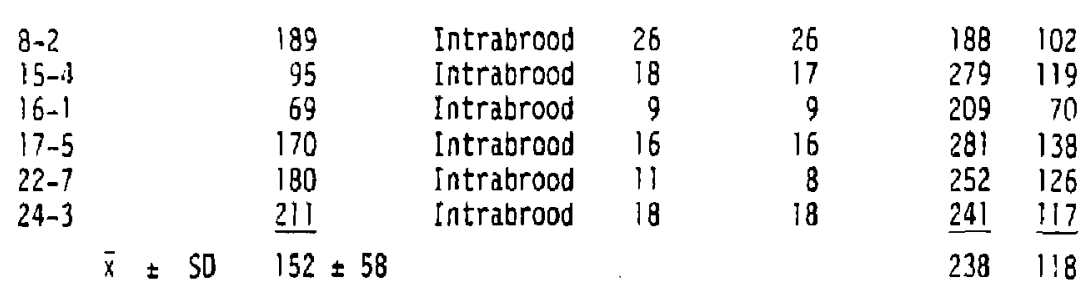

B. $0.19 m G y / h$

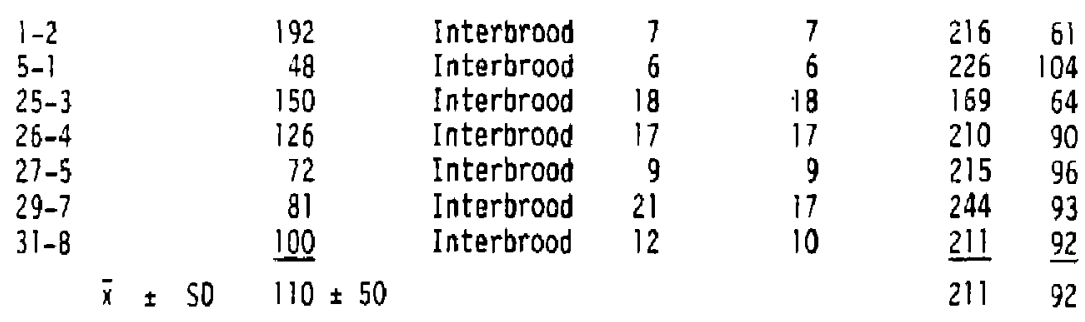

C. $2.1 \mathrm{mG} y / \mathrm{h}$

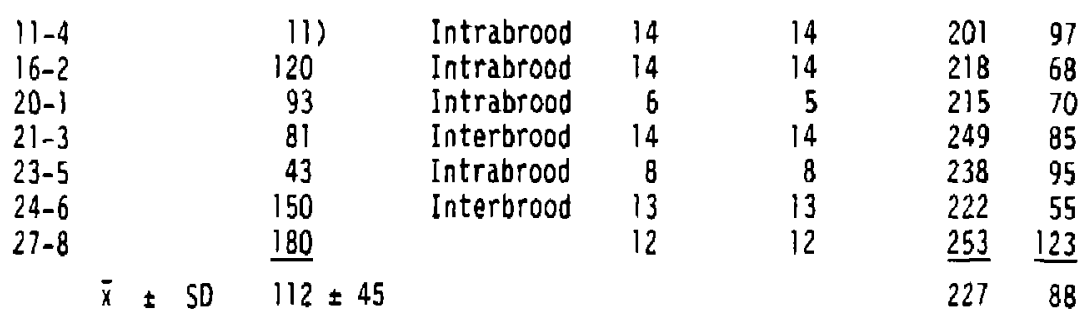

D. $17 m G y / h^{d}$

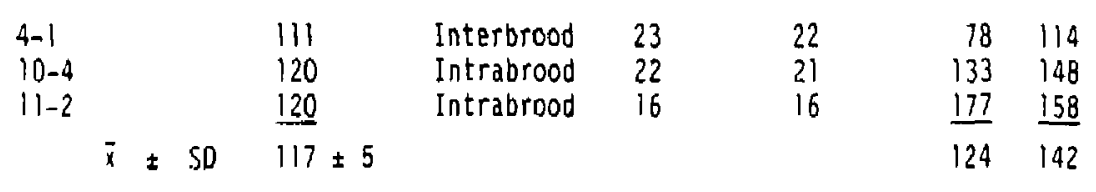

a females that resorbed their eggs and then died were included in the compilation as having a brood size of zero. 
Table 4. Number of embryos in broods from the control and radiation-exposed mated pairs. The broods were sacrificed before hatching occurred and were asstgned to one of four categories $(n \geq 150,150>n \geq 100,100, n \geq 50$, and $n<50$ ), according to the number of embryos in the brood.

$\begin{gathered}\text { Experimental } \\ \text { group }\end{gathered} n+150 \quad 150>n \geq 100100>n \geq 50 \quad n<50^{2}$ broods

A. Number of broods in category

$\begin{array}{lrrrrr}\text { Control } & 73 & 10 & 9 & 2 & 94 \\ 0.19 \mathrm{mGy} / \mathrm{h} & 64 & 12 & 6 & 2 & 84 \\ 2.1 \mathrm{mGy} / \mathrm{h} & 70 & 6 & 3 & 1 & 80 \\ 17 \mathrm{mGy} / \mathrm{h} & 23 & 6 & 4 & 26 & \frac{59}{317}\end{array}$

$\begin{array}{lrrrrr}\text { Control } & 77.7 & 10.6 & 9.6 & 2.1 & 94 \\ 0.19 \mathrm{mGy} / \mathrm{h} & 76.2 & 14.3 & 7.1 & 2.4 & 84 \\ 2.1 \mathrm{mGy} / \mathrm{h} & 87.5 & 7.5 & 3.8 & 1.2 & 80 \\ 17 \mathrm{mGy} / \mathrm{h} & 39.0 & 10.2 & 6.8 & 44.1 & \frac{80}{317}\end{array}$

a Females that resorbed their eggs and then died were included in the compilation as having a brood size of zero.

significantly from that of the control group, but that of the $17 \mathrm{mG} / \mathrm{h}$ group did (one way ANOVA $F=15.04, p<0.0001)$. The group receiving $17 \mathrm{mGy} / \mathrm{h}$ was significantly different from the controls because 25 of the 59 females resorbed their eggs and then died at approximately the time of spawning, and these females were included in the compilation as having a brood size of zero. These data indicate that these levels of radiation, which were received over the lifetime of the female worms and ranged from about 0.6 to $6.5 \mathrm{~Gy}$, did not result in a reduced number of $F_{2}$ embryos in the brood.

\subsection{Living Embryos in $F_{1}$ Broods}

For each brood from a $F_{1}$ mated pair, the percentage of the $F_{2}$ embryos that were living (as evidenced by the exclusion of trypan blue from their cells) was calculated for the group of control worms and for each of the groups of worms that were exposed to one of the three dose rates of radiation. The percentages, which were distributed into four categories $(n \geq 75 \%, 75 \%>n \geq 50 \%, 50 \%>n \geq 25 \%$, and $n<25 \%$, were related to the dose rate received. For the control group, almost all the developing $F_{2}$ embryos in the broods were living. Of the 90 control broods, 10 of these broods were in the $n \geq 75 \%$ category; stated as a percentage, $86.7 \%$ of the control broods were in the $n \geq 75 \%$ category (Table 5). In contrast, the percentage of the broods in which $n \geq 75 \%$ of the embryos were living in the 0.19 mGy/h group was 62.1: in the $2.1 \mathrm{mG} / \mathrm{h}$ group was $49.3 ;$ and in the $17 \mathrm{mG} / \mathrm{h}$ group was 3.4 . 
Table 5. Results from the trypan-blue-exclusion test of the living, dying, and dead $F_{2}$ embryos in the broods from the $F_{1}$ mated pairs. The broods were sacrificed before hatching occurred and were assigned to one of four percentage categories $(n \geq 75 \%, 75 \%>n \geq 50 \%, 50 \%>n \geq 25 \%$, and $n<25 \%$ ), according to the percentage of living embryos in the brood.

Experimental Categories of percentages of living embryos in broods
group

A. Number of broods in category

$\begin{array}{lrrrrr}\text { Control } & 78 & 5 & 1 & 6 & 90 \\ 0.19 \mathrm{~m} \mathrm{j} y / \mathrm{h} & 36 & 13 & 5 & 4 & 58 \\ 2.1 \mathrm{mGy} / \mathrm{h} & 34 & 15 & 12 & 7 & 69 \\ 17 \mathrm{mGy} / \mathrm{h} & 2 & 5 & 5 & 47 & \frac{59}{276}\end{array}$

B. Percent of broods in category

$\begin{array}{lrrrrr}\text { Control } & 86.7 & 5.6 & 1.1 & 6.7 & 90 \\ 0.19 \mathrm{mGy} / \mathrm{h} & 62.1 & 22.4 & 8.6 & 6.9 & 58 \\ 2.1 \mathrm{mGy} / \mathrm{h} & 49.3 & 23.2 & 17.4 & 10.1 & 69 \\ 17 \mathrm{mGy} / \mathrm{h} & 3.4 & 8.5 & 8.5 & 79.6 & \frac{59}{276}\end{array}$

a Females that resorbed their eggs and then died were included in the compilation as broods with $n=0 \%$ living embryos.

The results from the trypan-blue-exclusion test indicate that with increased dose rate there is a decreased percentage of living embryos in the brood (Fig. 5). Using the Test for Equal Proportions, we determined that tire number of broods in the $n ? 75 \%$ category for the group of worms exposed to $0.19 \mathrm{mGy} / \mathrm{h}$ was significantly different from the number in that category for the group of control worms: $x^{2}=12.06, p<0.001$. The proportion of the broods that was in the $n \geq 75 \%$ category for each of the other more intensely radiated groups was also significantly different from that of the control group ( $p<0.001)$. These results indicate that, for this species, a lifetime dose rate as low as $0.19 \mathrm{mGy} / \mathrm{h}$ or a total dose of about $0.6 \mathrm{~Gy}(60 \mathrm{rad})$ reduces significantly the percentage of living embryos in the brood.

The brooding males are effective at removing dead embryos from the brood. This is evident from the data acquired on the broods in which the embryos hatched into larvae before they were analyzed (see comment section of brood data in the Appendix). When hatching did occur, the percentage of living embryos almost always approached 100 . If large numbers of early-stage embryos are eaten by the male, his gut is yellow from the yolk consumed: these 


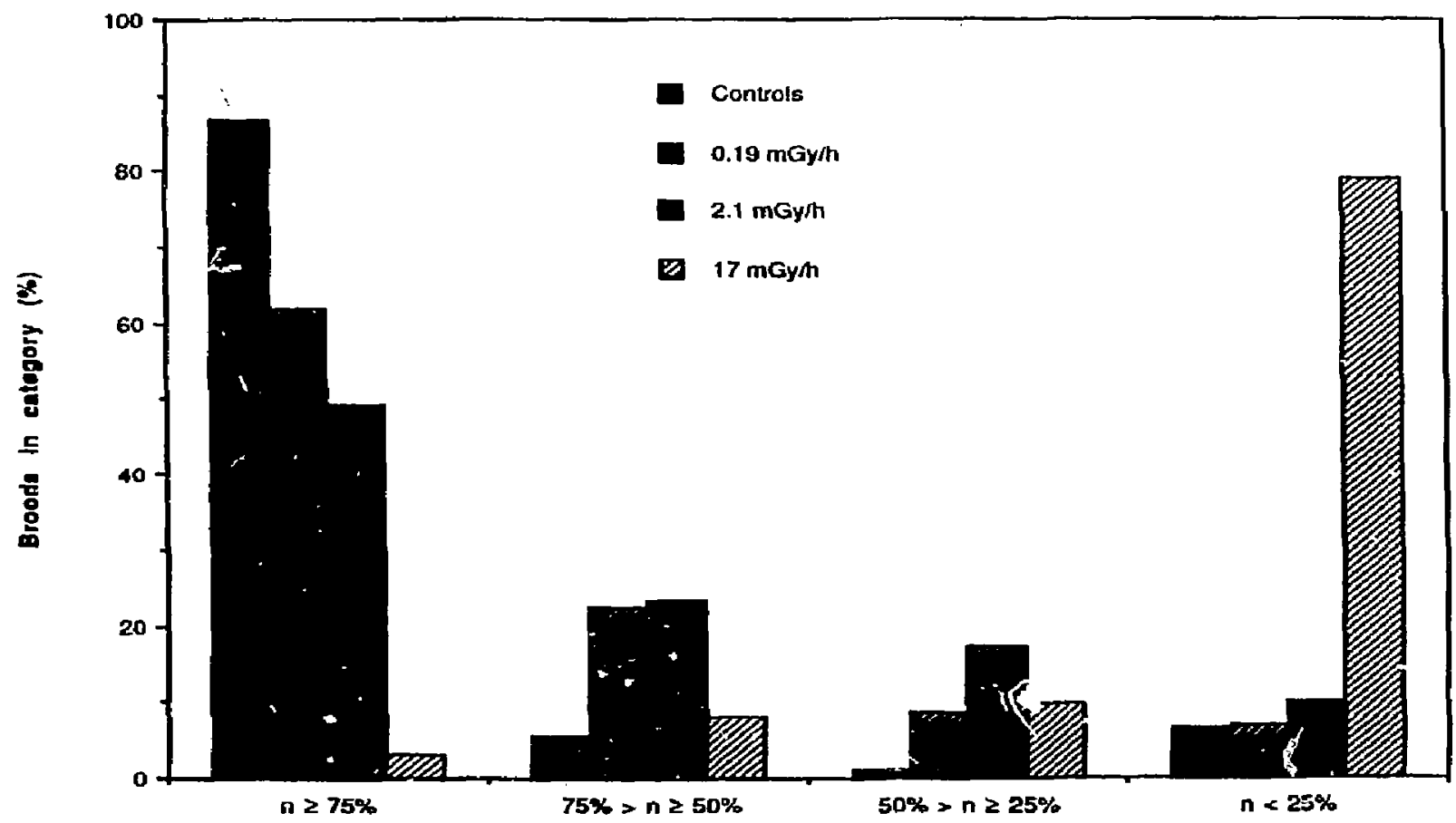

Figure 5. The percent of broods from the $F_{1}$ mated pairs in each of four categori:s $(n \geq 75 \%$, $752>n \geq$ 50\%, $50 \%>n \geq 25 \%$, and $n<25 \%$ ) of percent liviny embryus in the brood. 
males are referred to as cannibals. A few niales, even in the control group, cannibalized the brood, but at the higher dose rates this was a common occurrence, presumably because there were more dead embryos present. The percentage of the males that were cannibals was 17 in the control group, 27 in the $0.19 \mathrm{mGy} / \mathrm{h}$ group, 24 in the $2.1 \mathrm{mGy} / \mathrm{h}$ group, and 83 in the $17 \mathrm{mGy} / \mathrm{h}$ gruup.

\subsection{Abnormal Embryos in $F_{1}$ Broods}

In most broods, some embryos were ciassified as abnormal because of their morphology or because their deveiopment was delayed severely. The broods were placed into four categories $(n \geq 150,150>n \geq 100,100>n \geq 50$, and $n<50$ ), according to the number of abnormal embryos in the brood (Table 6 , Fig. 6). The percant of the broods in the $n$ ( 50 category was 80.2 for the control group and was $60.7,35.3$, and 5.1 for the groups exposed to $0.19,2.1$, and $17 \mathrm{mGy} / \mathrm{h}$, respectively. We also calculated the percentages of annormal embryos that were present, and these were distributed into four categories $\langle n \geq 75 \%, 75 \%\rangle n \geq 50 \%, 50 \%\rangle n \geq 25 \%$, and $n<25 \%$ )(Table 7, Fig. 7). The percent that was in the $n \geq 75 \%$ category was I for the control group and 7 . 16. and 91 for the groups exposed to $0.19,2.1$, and $17 \mathrm{mGy} / \mathrm{h}$, respectively. Incidence of abnormal embryos appears to be dose related. A significant difference from the contrnl group was detected in all the radiation-exposed groups. For the group exposed to $0.19 \mathrm{mG} / \mathrm{h}, \mathrm{x}^{2}=6.66, \mathrm{p}<0.005$.

\section{Reduced Survival of $F_{1}$ Embryos}

The numbers of embryos that were estimated to hatch or the actual numbers that hatched were grouped into four categories: $(n>150,150>n>100,100>$ $n ? 50$, and $n(50)$ (Table 8). The hatch size was related to dose rate ifig. 8). The percent of the broods that had or were estimated to have hatcilings $>150$ in nurioer was 68.1 for the control group and was 50.0,36.3. and 0 for the radration-exposed groups receiving $0.19,2.1$, and $17 \mathrm{mg} y / \mathrm{h}$, respectively. Also, the estimated size of the hatch from the $F_{1}$ mated pairs exposed to radiation was sigrificantly different from that of controls for ali the lifetime dose rates delivered to the worms.

The effects of radiation were apparent also in the percentage of broods in which the EHS was zero. The percentage was 1.2 for the control group and was $5.4,7.7$, and 42.3 for the groups exposed to $0.19,2.1$, and $17 \mathrm{mGy} / \mathrm{h}$, respectively. An EHS of zero resulted because the female resorbed the eggs or because the embryos in the brood were either abnormal, dead, or dying.

The effects of radiation on the potential for embryos to survive to hatching was assessed. The percent of the embryos that should survive to hatching for each brood was calculated by dividing the EHS by the brood size and multiplying the fraction by 100 . Then, the broods were assigned to one of four categories $(n \geq 75 \%, 75 \%) n>50 \%, 50 \%, n) 25 \%$, and $n<25 \%$ ), according to the percentages of survival (Table 9, Fig. 9). The Test for Equal Proportions was $u$ ed to determine which radiation groups had distributions of perceniages that were significantly different from that of the controls. All groups axposed to radiation were significantly di?ferent from controls; the p values were $<0.001$. 
Table 6. Results from the analys is of the normal and abnormal embryos in the broods from the control and radiation-exposed $F_{1}$ mated pairs. The broods were sacrificed before hatching occurred and were assigned to one of four categories ( $n, 150,150, n \geq 100,100>n \geq 50$, and $n(50)$, according to the number of abnormal embryos in the brood.

\section{Experimental Categories of numbers of abnormal embryos in broods Total group $\quad n \geq 150 \quad 150>n \geq 100 i 00>n \geq 50$ n<50d broods}

A. Number of broods in category

$\begin{array}{lrrrrr}\text { Control } & 4 & 7 & 7 & 73 & 91 \\ 0.19 \mathrm{mGy} / \mathrm{h} & 5 & 6 & 11 & 34 & 56 \\ 2.1 \mathrm{mGy} / \mathrm{h} & 17 & 10 & 17 & 24 & 68 \\ 17 \mathrm{mGg} / \mathrm{h} & 47 & 4 & 5 & 3 & 59 \\ & & & & & 274\end{array}$

8. Percent of broods in category

$\begin{array}{lrrrrr}\text { Control } & 4.4 & 7.7 & 7.7 & 80.2 & 91 \\ 0.19 \mathrm{mGy} / \mathrm{h} & 8.9 & 10.7 & 19.6 & 60.7 & 56 \\ 2.1 \mathrm{mGg} / \mathrm{h} & 25.0 & 14.7 & 25.0 & 35.3 & 68 \\ 17 \mathrm{mGy} / \mathrm{h} & 79.6 & 6.8 & 8.5 & 5.1 & \frac{59}{274}\end{array}$

a Females that resorbed their eggs and then died were included in the compilation as broods in the $n \geq 150$ category.

An analysis was performed to deternine the relationship between chronic radiation dose and embryo survival. The mean percent survival for the control group and for each radiation-exposed group was determined. For the control group, a value of $82 \pm 18 \%$ was obtained, and for the groups exposed to radiation, the values were $61 \pm 28 \%$ for the group exposed to $0.19 \mathrm{mG} / \mathrm{h}$, $51 \pm 31 \%$ for the group exposed to $2.1 \mathrm{mGy} / \mathrm{h}$, and $5 \pm 13 \%$ for the group exposed to $17 \mathrm{mGy} / \mathrm{h}$. The mean percentage for each radiation-exposed group was expressed also as a percentage of the control group. A semilog plot of percentages versus dose resulted in a straight line; an $\mathrm{LO}_{50}$ of about $10 \mathrm{~Gy}$ and an $109 g$ of about 100 Gy was obtained (Fig. 10).

Other parameters that were examined for the experimental animals were (1) the time from spawning of the $P_{1}$ brood to the hatching of the $F_{1}$ larvae (spawn-to-hatch time) and (2) the time from the hatching of the larvae $\left(F_{1}\right)$ until the spawning of the adult females $\left(F_{1}\right)$ (hatch-to-spawn time). The mean spawn-to-hatch time for all the $P_{1}$ broods was $11.7 \pm 1.80$, and the irradiated groups did not differ significantly from controls. These data indicate that 


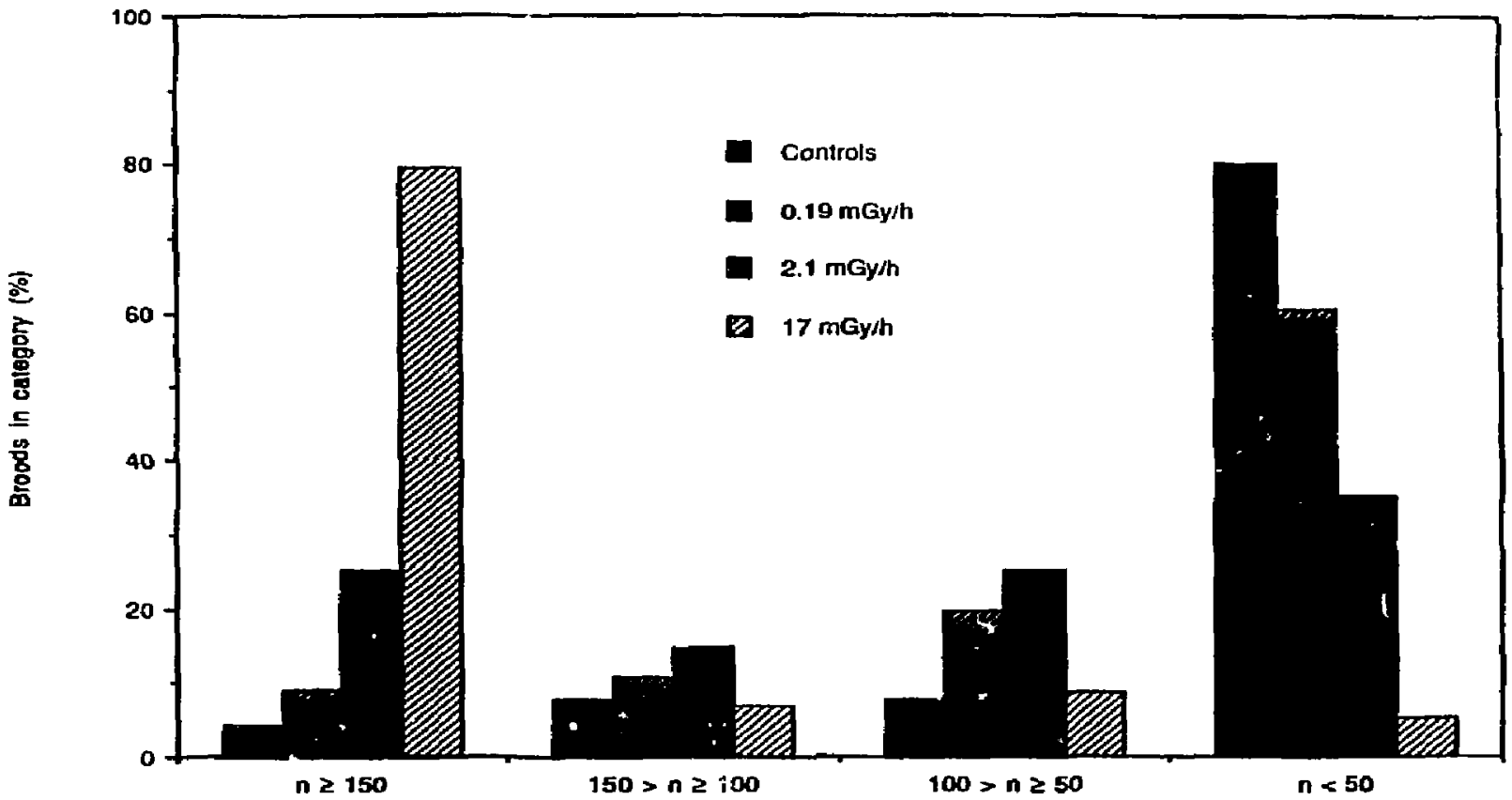

Figure 6. The percent of broods from F, mated pairs in each of four categories $(n \geq 150,150) n \geq$ 100. $100, n \geq 50$, and $n<50$ ) of numbers of abnormal embryos in the brood. 
Table 7. Results from the analysis of normal and abnormal embryos in the broods from the control and radiation-exposed mated pairs The broods were sacrificed before hatching occurred, the number of normal and abnormal embryos determined, the percent of abnormal embryos calculated, and then the broods were assigned to one of four categories $(n \geq 75 \%, 75 \%>n \geq 50 \%, 50 \%>n \geq$ $25 \%, n(25 \%)$, according to the percent of abnormal embryos in the brood.

$\left.\begin{array}{c}\text { Experimental } \\ \text { group }\end{array} \frac{\text { Categories of percentages of living embryos in broods }}{n \geq 75 \%} \quad 75 \%\right) n \geq 50 \% \quad 50 \%>n \geq 25 \% \quad n<25 \%$ broods

A. Number of broods in category

$\begin{array}{lrrrrr}\text { Control } & 1 & 2 & 9 & 77 & 89 \\ 0.19 \mathrm{mGy} / \mathrm{h} & 4 & 15 & 15 & 23 & 57 \\ 2.1 \mathrm{mGy} / \mathrm{h} & 11 & 19 & 16 & 22 & 68 \\ 17 \mathrm{mGy} / \mathrm{h} & 54 & 4 & 1 & 0 & \frac{59}{273}\end{array}$

$\begin{array}{lrrrrr}\text { Control } & 1.1 & 2.2 & 10.1 & 86.6 & 89 \\ 0.19 \mathrm{mG} / \mathrm{h} & 7.0 & 26.3 & 26.3 & 40.4 & 57 \\ 2.1 \mathrm{mGg} / \mathrm{h} & 16.2 & 27.9 & 23.5 & 32.4 & 68 \\ 17 \mathrm{mGy} / \mathrm{h} & 91.5 & 6.8 & 1.7 & 0 & \frac{59}{273}\end{array}$

a Females that resorbed their eggs and died were included in the compilation as broods with 100\% abnormal embryos.

when worms were irradiated with doses as high as $17 \mathrm{mGg} / \mathrm{h}$ and were given a total dase of 4.9 Gy during the spawn-to-hatch time, the time required to develop from fertilized eggs to larvae was not affected. The mean spawn-to-harvest time for all the $F_{1}$ females was $127 \pm 18 \mathrm{~d}$, and there were no significant differences among experimental groups. These data indicate that radiation at doses as high as $17 \mathrm{mGy} / \mathrm{h}$ and mean total doses of about $54 \mathrm{~Gy}$ also did not affect the life span of the females.

\section{DISCUSSION}

Living organisms are exposed to radiation from natural sources and from anthropogenic sources, including nuclear explosions, routine and accidental releases from nuclear power facilities, and nuclear waste disposal (UNSCEAR 1977, 1982). The dose rates to marine organisms from natural background radiation, global fallout, and waste radionuclides were calculated by Woodhead (1984) and provide a perspective within which the possible harmful effects of increased radiation exposure can be considered. The dora rates in the marine environment due to radionuclide inputs arising from human activities range from less than the natural background exposure for typical nuclear power stations in routine osirations up to a few tanths of mGy/h for the rather exceptional case of tile Windscale discharge iritn the nor theast Irish Sea (Woodhead 1984). 


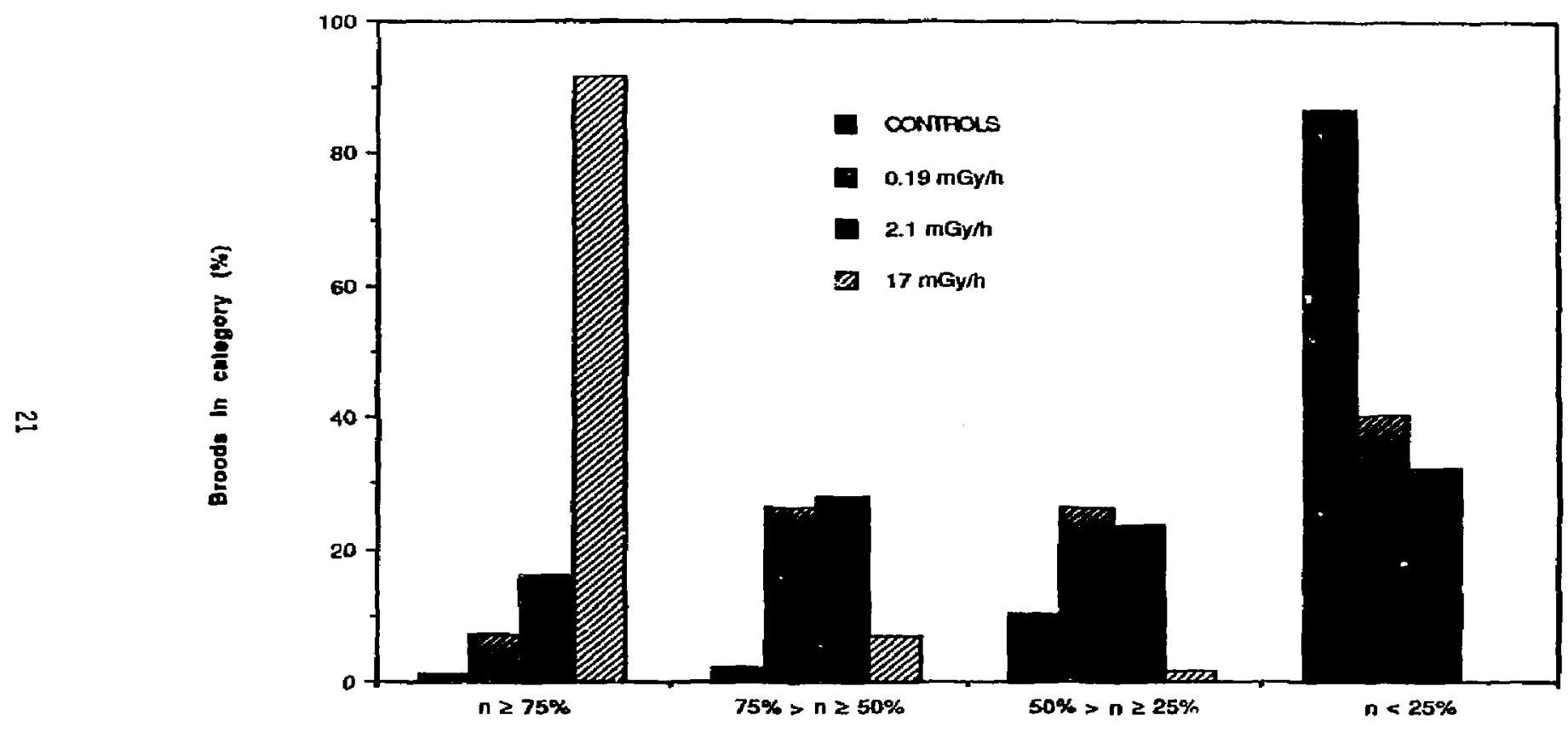

I igure 7. The percent of broods in edch of four categories $(n \geq 75 \%, 75 \%>n \geq 50 z, 50 \%>n \geq 25 z$, and $n$ ( $25 \%$ ) of percent abnormal embryas in the brood. 
Table 8. Results from the analysis of the number's of $F_{2}$ embryos that actually hatched or were estimated to hatch from the broods of the control and radiation-exposed $F_{1}$ mated pairs. The broods were assigned to one of four categories $(n \geq 150,150>n \geq 100,100>\geq 20$, and $n\langle 50)$, according to the actual or estimated hatch size.

$\underset{\text { group }}{\text { Experimental }} \frac{\text { Categories of numbers estimated or actually in hatches }}{n \geq 150} 150>n \geq 100100>n \geq 50$ Total

A. Number of broods in category

$\begin{array}{lrrrrr}\text { Control } & 64 & 12 & 10 & 8 & 94 \\ 0.19 \mathrm{mGy} / \mathrm{h} & 42 & 18 & 14 & 10 & 84 \\ 2.1 \mathrm{mGy} / \mathrm{h} & 29 & 20 & 14 & 17 & 80 \\ 17 \mathrm{mGy} / \mathrm{h} & 0 & 1 & 3 & 57 & \frac{61}{319}\end{array}$

B. Percent of broods in category

$\begin{array}{lccrrr}\text { Control } & 68.1 & 12.8 & 10.6 & 8.5 & 94 \\ 0.19 \mathrm{mGy} / \mathrm{h} & 50.0 & 21.4 & 16.7 & 11.9 & 84 \\ 2.1 \mathrm{mGy} / \mathrm{h} & 36.3 & 25.0 & 17.5 & 21.3 & 80 \\ 17 \mathrm{mGy} / \mathrm{h} & 0 & 1.6 & 4.9 & 93.4 & \frac{61}{319}\end{array}$

It is well documented that radiation induces biological effects through the deposition of energy in the cells of the irradiated individuals (UNSCEAR 1982). If the effects are produced in the somatic cells, they must become apparent, by definition, within the life of the irradiated organism. If the effects are produced in the germ cells, whose function is to transmit genetic information to new individuals, the effects may be detected in the descendants of the irradiated individual in the first or subsequent generations.

Most of the information avilable on radiation effects on reproductive success in aquatic animals is on the effects of acute radiation. Effects were determined by irradiating early life stages and adults (see reviews by Egami and Ijiri 1979; Woodhead 1984; Anderson and Harrison 1986). The effects of acute radiation on processes affecting reproductive success in aquatic invertebrates were reported for doses that range over at least two orders of magnitude (Cervini and Giavelli 1965; Ravera 1967; Hoppenheit 1973; Greenoerger et al. 1986; Anderson et al. 1987). Causes for this broad range seen, to be not only actual species-specific differences in gamete sensitivity, but also differences in the gamete stage irradiated and in the cell-repopulation capacity of different organisms. 


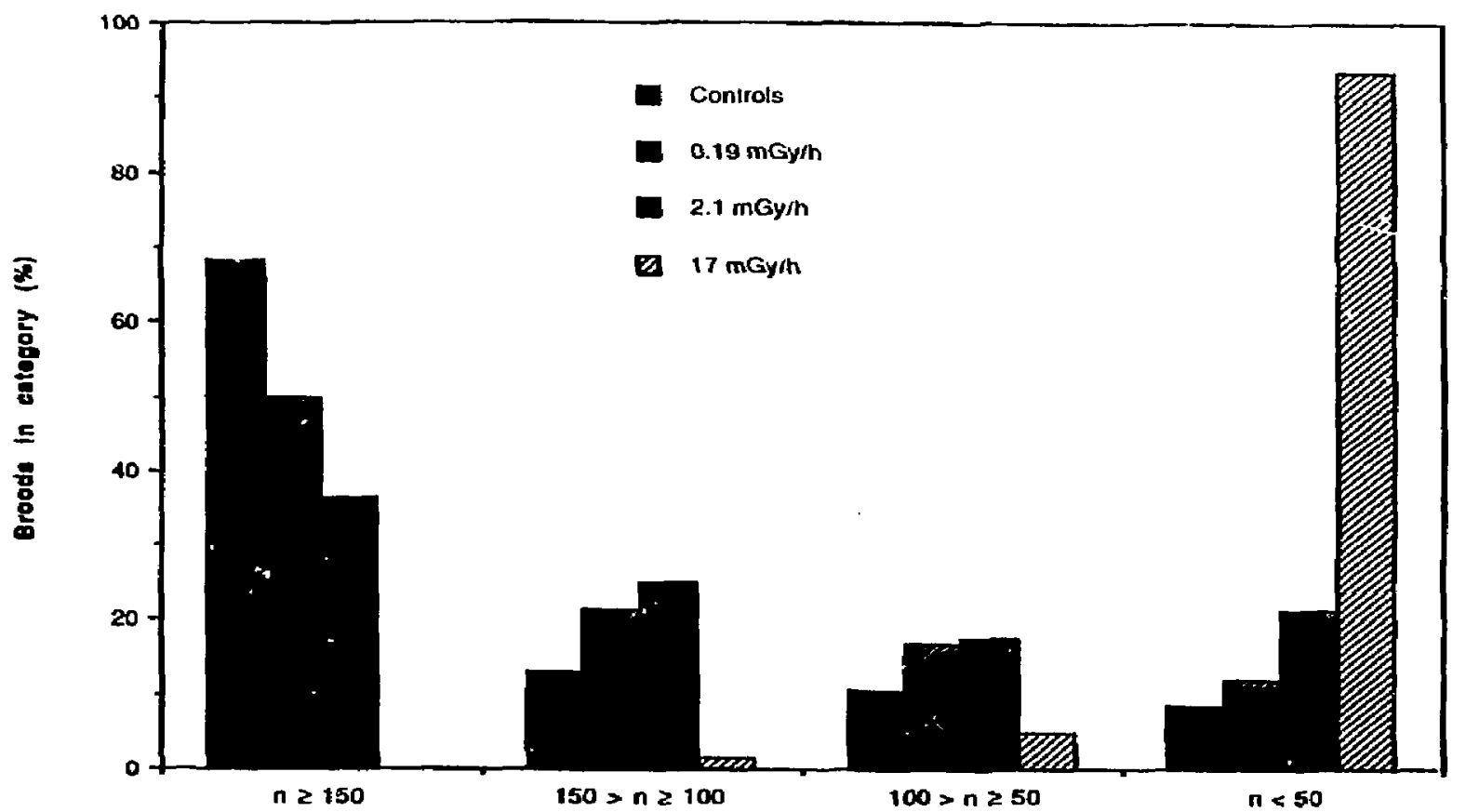

Figure 8. The percent of broods from the $F_{1}$ mated pairs ill each of four categories $(n \geq 150,150>n \geq$ $100,100>n \geq 50$, and $n<50)$ of actual and estimated numbers of hatchilings. 
Table 9. Results of the analysis of survival to hatching of embryos in the broods of the control and radiation-exposed $f$ m mated pairs. The percent survival was calculated by dividing the estimated hatch size by the brood size, and then the broods were assigned to one of four categories ( $n \geq 75 \%$, $75 \%, n \geq 50 \%, 50 \% \cdot n \geq 25 \%$, and $n(25 \%)$, according to the percent survival of the embryos.

Experimental
griup

A. Number of broods in category

$\begin{array}{lrrrrr}\text { Control } & 68 & 9 & 2 & 2 & 81 \\ 0.19 \mathrm{mGy} / \mathrm{h} & 20 & 17 & 13 & 5 & 55 \\ 2.1 \mathrm{mGg} / \mathrm{h} & 21 & 13 & 18 & 13 & 65 \\ 17 \mathrm{mGy} / \mathrm{h} & 0 & 1 & 3 & 47 & \frac{51}{252}\end{array}$

8. Percent of troods in category

$\begin{array}{lcrrrr}\text { Control } & 84.1 & 11.0 & 2.5 & 2.5 & 81 \\ 0.19 \mathrm{mGy} / \mathrm{h} & 36.4 & 30.9 & 23.0 & 9.1 & 55 \\ 2.1 \mathrm{mGy} / \mathrm{h} & 32.3 & 20.0 & 27.7 & 20.0 & 68 \\ 17 \mathrm{mGy} / \mathrm{h} & 0 & 2.0 & 5.9 & 92.1 & \frac{51}{252}\end{array}$

a Data from broods that hatched or that were harvested before day 3 were excluded.

Studies were conducted to assess the effects of chronic iow-level radiation on reproduction in fishes and invertebrates, and a number of these were conducted over a full life cycle. However, most of the experiments to assess the effects of chronic radiation were performed using radionuclides in the water and the doses delivered were uncertain (Woodhead 1984; Anderson and Harrison 1986).

Information on the effects of chronic radiation on reproductive success in fishes and aquatic invertebrates is available from studies in which the effects of relatively low dose rates were investigated. Trabalka and Allen (1977) compared populations of the ilosquitofish Gambusia affinis from the radionuclide-contaminaied White Oak Lake at the Oak Ridge National Laboratory to those from a matched control site. They found no decrease in fecundity, but an increase in embryo mortality of the fish from White Oak Lake; these fish received about $0.25 \mathrm{mGy} / \mathrm{h}$. These results were confounded by the fact that contaminants other than radionuclides were present in white 0ak Lake. Cooley (1973) examined the reproductive biology of fond 


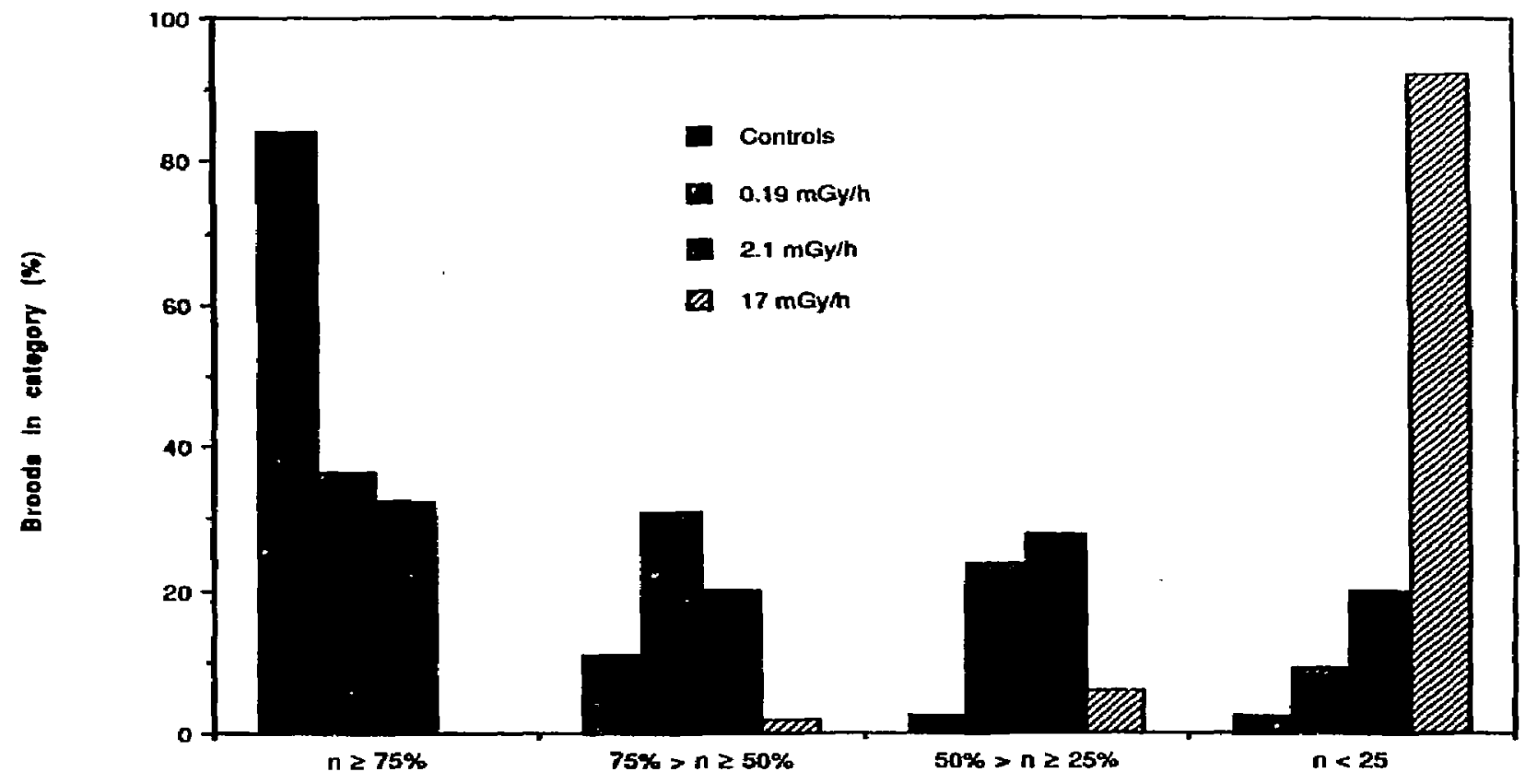

Figure 9. The percent of broods in each of four categories ( $) \geq 75 \%, 75 \%>n \geq 50 \%, 50 \%>n \geq 25 \%$, allu $n$ ( $25 \%$ ) of percent survival to hatcliing of the embryos in the brood. 


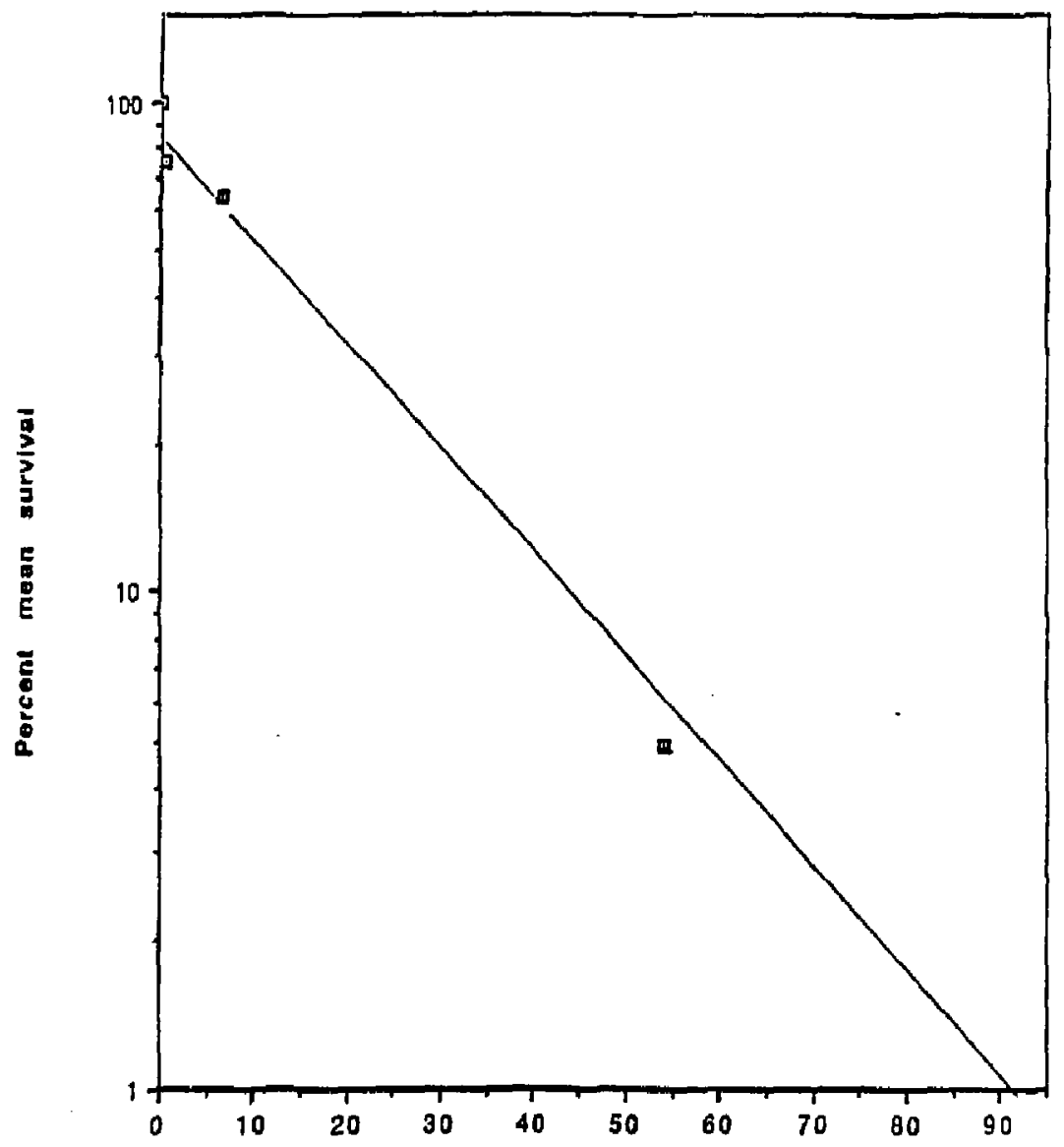

$\operatorname{Dose}(\mathrm{G} y)$

Figure 10. Mean percent survival of embryos (expressed as percentage of the survival fraction of the controls) as a function of chronic dose. Data from broods that hatched or that were harvested before day 3 were excluded. 
snails from White Oak Lake; these were exposed to about the same dose rate as the mosquitofish. He found that frequency of egg-capsule production was reduced; however, an increased number of eggs per capsule was also documented. It is interesting to note that a prior laboratory study by Coaley and Miller (1971) documented a clear cut reproductive decline at 240 radid $(100 \mathrm{mGy} / \mathrm{h})$ but not at $24 \mathrm{rad} / \mathrm{d}$. Irradiation was initiated on $45-d-0 / d$ snails, and laboratory effects might have been observed at lower levels if irradiation had been extended over the entire lifetime of the organism.

One of the most rigorous studies involving chronic exposure to radiation was that of Woodhead (1977), who examined fecundity of the guppy Poecilia reticulata receiving $4.08,9.6$, and $30.5 \mathrm{rad} / \mathrm{d}(1.7,4.0$, and $12.7 \mathrm{mGy} / \mathrm{h})$. Total fecundity was significantly reduced at all dose rates. Reductions in fecundity were probably due to both reproductive effects (damage to gametes) and the induction of dominant-lethal mutations in gametes. Effects on gonadal cells wcre reported also for Gambusia affinis (Cosgrove and Blaylock 1973) and for aryzias latipes (Hyodo-Taguchi and Egami 1977; Hyodo-Taguchi 1980). Hyodo-Taguchi (1980) observed an increased percentage of unfertilized Oryzias latipes eggs after males used to inseminate the eggs received approximately $6.9 \mathrm{rad} / \mathrm{d}(2.9 \mathrm{mGy} / \mathrm{h})$ for $60 \mathrm{~d}$. No statistically significant effects were observed at $2.9 \mathrm{rad} / \mathrm{d}$, the next lover dose rate used. Bonham and Donaldson (1972) exposed Chinook salmon Oncorhynchus tschawytscha enbryos for the first $80 \mathrm{~d}$ of life to 0.19 to $17 \mathrm{R} / \mathrm{d}$ (about 0.08 to $6.8 \mathrm{mGy} / \mathrm{h}$ ). Approximately $4 \mathrm{wk}$ after the irradiations were completed, gonadal development was observed in smolts. They found that gonadai development was retarded in those receiving at least $10 \mathrm{R} / \mathrm{d}$.

In a more recent study, Rackham and Woodhead (1984) examined the effects of chronic garma irradiation on the gonads of the adult fish Ameca splenden. The dose rate used was $7.3 \mathrm{mGy} / \mathrm{h}$; after an accumulated dose of $0.95 \mathrm{~Gy}$, spermatogenesis was disrupted, and after an accumulated dose of $9.7 \mathrm{~Gy}$, there was no further production of sperm.

It is apparent from the data available that direct comparisons of sensitivity among species irradiated chronically are often not valid because the duration of the radiation differed from partial to several lifetimes. Research on effects of chronic radiation on the gonads is of particular interest, however, because the results show effects levels comparable to those observed in mamals. Dose rates between 0.2 and $4 \mathrm{mGy} / \mathrm{h}$ appear to define a critical range in which detrimental effects on processes contributing to reproductive success are first observed in a variety of sensitive organisms.

In our study, the effects of lifetime radiation on reproductive success of a relatively low fecundity species were evaluated. Information was obtained on the effects of chronic radiation on total number of developing embryos in the brood, on the numbers of normal and abnarmal embryos in the brood, on the numbers of embryos that were living, dying, and dead, and on the estimated number of hatchlings. Comparisons were made of the data from control worms and from worms that were exposed to radiation immediately after fertilization occurred until they released their gametes and the next generation of zygotes were formed. Thus, germ cells were irradiated from thetr time of origin (primordial germ cells) until mature gametes were released. 
An important effect of lifetime irradiation of $\mathrm{N}$. arenaceodentata with low dose rate $(0.19$ and $2.1 \mathrm{mg} / \mathrm{h})$ was increased mortality of the embryos $\left(F_{2}\right.$ generation). There was no evidence for $F_{1}$ gamete death or for reduced fertilization success because the number of developing embryos in the broods did not decrease. However, at the highest dose rate used, $17 \mathrm{mG} / \mathrm{h}$, brood size was affected and was related to the resorption of oocytes in the females. Also, at all three dose rates used, there was no detectable effect on the time required for the fertilized eggs to develop into larvae or on the life span of the female $F_{1}$ worm.

Increased mortality of the $F_{2}$ embryos was indicated because both the number of dead and dying embryos and the number of abnormal embryos found in the brood after 4 to 6 days of development increased with increased dose rate. Both of these factors contributed to a decreased number of actual or estimated number of hatchlings in the broods and occurred at the lowest rate used, $0.19 \mathrm{mGy} / \mathrm{h}$. The increased mortality was most likely from the induction of lethal mutations in the gern cells during gametogenesis. Because both the males and females were given lifetime irradiation and because little is known about the comparative sensitivity of cells in the different stages of oogenesis and spermatogenesis in $\mathbf{N}$. arenaceodentata, it is not known whether the lethal mutations occurred primarily ouring oogenesis, spermatogenesis, or relatively equally during both of these processes.

Effects of acute radiation on reproduction of $N$. arenaceodentata were examined in a companion study (Harrison and Anderson 1988), and comparisons of the effects on reproduction of total doses received from acute and chronic radiation were made (Table 10). For the parameters compared, the control group for the worms irradiated acutely appeared to be less vigorous than for those irradiated chronically; there was a greater proportion of small broods, fewer living embryos, etc. The differences between the two control groups may have been due to differences in their maintenance conditions. For the experiment in which the mated pairs were irradiated chronically, the broods were from females that were raised in our laboratory under uniform conditions of food availability and temperature whereas for those irradiated acutely, the females were from multiple sources and may not have been raised under similar conditions.

Effects on brood size, which may be due to oocyte killing, were seen when a total dose of 50 Gy was given over the lifetime of the female and when an acute dose of 10 or 50 Gy was given at the time oocytes vere visible in the coelom. Information available from the mouse indicates that the target for cell killing and that for genetic effects are different and distinct in this species: the lethality target in immature oocytes appears to be the plasma membrane and the sensitivity of this target differs almost two orders of magnitude with stage in the mouse life cycle (Straume et a1. 1987; Straume et al. 1988). For $\underline{N}$. arenaceodentata, we do not have sufficient radiobioiogical information to evaluate the effect of developmental stage on oocyte radiosensitivity.

Comparison of the values (except brood size) that were corrected for controls shows that for those broods from females receiving a total dose of about 0.5 or 5 Gy, the effects were similar or greater for those irradiated acutely (Table 10). However, the differences between the effects elicited by 
Table 10. Comparison of the effects of acute and chronic irradiation on Neanthes arenaceodentata. The values are percents of the broods in the category indicated.

\begin{tabular}{|c|c|c|c|c|c|c|c|c|}
\hline Effects & $\frac{\text { Acute }}{\text { Control }}$ & $\frac{\text { Chronic }}{\text { Control }}$ & $\frac{\text { Acute }}{0.5 \text { Gy }}$ & $\frac{\text { Chronic }}{0.55 \text { Gy }}$ & $\frac{\text { Acute }}{5.0 \mathrm{G} y}$ & $\frac{\text { Chronic }}{6.5 \mathrm{~Gy}}$ & $\frac{\text { Acute }}{50 G y}$ & $\frac{\text { Chronic }}{54 \text { Gy }}$ \\
\hline Broad sizea & 10 & 2 & 15 & 2 & 26 & $\mathbf{1}$ & 56 & 44 \\
\hline (n< 50 category) & & & (5) & $(0)$ & $(16)$ & $(0)$ & $(46)$ & (42) \\
\hline Living embryos b & 57 & 87 & 31 & 62 & 22 & 49 & 14 & 3 \\
\hline$(n \geq 75 \%$ category) & & & $(54)$ & (71) & (39) & $(56)$ & $(25)$ & (3) \\
\hline Abnormal embryosa & 18 & 1 & 25 & 7 & 38 & 16 & 71 & 91 \\
\hline$(n \geq 75 z$ category) & & & (7) & (6) & $(20)$ & (15) & (53) & $(90)$ \\
\hline Estimated hatch sizea & 23 & $\mathbf{8}$ & 38 & 12 & 50 & 21 & 82 & 93 \\
\hline$(n<50$ category $)$ & & & (15) & (4) & $(27)$ & (13) & (59) & (85) \\
\hline Survival to hatchinga & 20 & 2 & 29 & 9 & 40 & 20 & 73 & 92 \\
\hline$(n<25 \%$ category) & & & (9) & (7) & $(20)$ & $(18)$ & (53) & $(90)$ \\
\hline Survival of embryosb & 60 & 82 & 48 & $6]$ & 39 & 52 & 20 & 5 \\
\hline (mean percent) & & & $(80)$ & (74) & $(65)$ & (63) & (33) & $(6)$ \\
\hline
\end{tabular}

a Values in parentheses are minus the control values or are expressed as percents of the control value.

b Values in parentineses are expressed as percents of the control value. 
Table 11. Comparison of the effects on reproductive success of exposure of Neanthes arenaceodentata to different doses of contaminants.

\begin{tabular}{|c|c|c|c|c|c|}
\hline \multirow[b]{2}{*}{ Response } & \multicolumn{2}{|c|}{$\begin{array}{l}\text { Ionizing } \\
\text { radiation } \\
(\text { Gy })\end{array}$} & \multirow{2}{*}{$\begin{array}{c}\begin{array}{c}\text { Hexaval ent } \\
\text { chromi uma } \\
(\mu g / L)\end{array} \\
\text { Chronic }\end{array}$} & \multirow{2}{*}{ ' } & \multirow{2}{*}{$\begin{array}{l}\text { Number } 2 \\
\text { fuel of ib } \\
\text { (\%NSF) } \\
\text { Chronic }\end{array}$} \\
\hline & Acute & Chronic & & & \\
\hline Sterility & $50^{C}$ & $90^{C}$ & 100 & & -- \\
\hline $\begin{array}{l}\text { Reduction in number } \\
\text { of embryos }\end{array}$ & 10 & 54 & -- & . & 2.5 \\
\hline $\begin{array}{l}\text { Reduction in number } \\
\text { of hatchlings }\end{array}$ & 0.5 & 0.55 & $16-38$ & & 2.5 \\
\hline
\end{tabular}

a Oshida and coworkers (1981, 1982).

$b$ Rossi and Anderson (1978); WSF is the water-soluble fraction.

C Effective starility is defined here as $1 \%$ survival of embryos to hatching as compared to controls.

radiation given acutely and that given chronically was less than was expected. These results indicate that there was most likely accumulation of radiation damage in nondividing cells and, then, this damage became apparent after fertilization when the cells started to divide. This finding is of special interest because such damage accumulation may occur not only with the direct-acting mutagen, radiation, but also with other direct- and indirect-acting organic mutagens that may be present in ecosystems. Although we have no direct evidence for such, the damage accumulation may be related to differences in DNA-repair ability of cells in different stages in ganetogenesis.

Comparison of the values (corrected for controls) for females receiving a total dose of about 50 Gy acutely and chroni-ally indicates that the effects appear to be more severe in those irradiated chronically. There are two plausible explanations for this response. First, all gametogenic stages are irradiated during chronic exposures and a particular stage of oocyte development may be sensitive to high dosa rates. This could be relatively short hypersensitive stage that is only "hit" by chronic radiation. Second, an unknown radiation-induced stress may have been induced at the high dose rate, and this stress may have caused resorption of the oocytes prior to spawning. The overall effect would oe reduced fecundity.

Evidence that the oocytes are the limiting cell system was obtained from a comparison of the data from the preliminary and final experiments on acute effects of radiation. In the preliminary experimer.t, only the females were irradiated (Anderson et al. 1987), while in the final experiment, mated pairs 
(male and female) were irradiated (Harrison and Anderson 1988). The results of both the preliminary and the final experiments were similar; this inticates that the oocytes were most likely the cells in which radiation damage was accumulated.

Information available on mamals indicates that in some species the oocytes are very sensitive to radiation (UNSCEAP 1966; Dobson er al. 1984; Dobson et al. 1986). Sensitive species include vice and sorile primates. In the mouse, the $L D_{50}$ for immature-0ocyte kiiling with ${ }^{6} C_{C}$ gamma rays is 1.75 Gy in the prenatal mouse and range from auout 0.05 to $0.15 \mathrm{~Gy}$ in the juvenile mouse. The value of 0.05 Gy for juvenile mice reflects about a 30 to 50 times greater sensitivity than found in most other cells studied. In the squirrel monkey, the $\mathrm{LO}_{50}$ for radiation from administering tritiated water was 0.07 Gy from prenatal exposure and 2.25 Gy from adult exposure. It is apparnnt that there are considerable differences in sensitivity with species and life stage. In $N$, arenaceodentata, we know little about differences in sensitivity with defined life stages. However, from the results we obtained, it appears that a dose at least 10 times higher is required to af iect cell killing in $\mathrm{N}$. arenaceodentata than in least sensitive stage of the mouse, but that the sensitivity of $\underline{N}$. arenaceodentata is in the range of most other celis studied.

Little is known about the effects of factors that riay modify the responses of aquatic organisms to radiation. Factors that nicy flay an important role are DNA repair, tissue oxygen concentrations, and environmental conditions, such as temperature, salinity, and water quality (Anderson and Harrison 1986). Some of these factors are known to modify the responses of vertebrates to radiation and require elucidation before conclusions are drawn about regulatory limits on the quantities of mutagens released in the crvironment.

Information is available for $N$. arenaceodentata on the effect on reproductive success of contaminants other than radiation (Table 11). Considerable data are available on the effects of chromium Coshida et al. 1981; Oshida and Ward 1982). Concentrations uf chromium as low as $16 \mu \mathrm{g} / \mathrm{L}$ reduced the numbers of hatchlings. The concentration of chromium that resulted in sterility was $100 \mu \mathrm{g} / \mathrm{L}$. However, sterility ocsurred not because of effects on gametes but because of a behavioral respunse of the adult worms. According to these investigators, the worms were jerking and twisting to such an extent that the prolonged contact required for reproduction did not occur.

The water-soluble fraction (WSF) of Number 2 fuel oil also impacted on reproduction in $\mathrm{N}$. arenaceodentata (Rossi and anderson 1978). Effects on the number of larvae that hatched occurred at concentrations as low as 2.5\% WSF (Table 11). No information was available on the WSF concentrations resulting in sterility, but growth was inhibited at 5 and $10 \%$ WSF. 
The studies of the effects of both chromium and fuel oil were multigeneration and provided evidence that there was accommodation to tire contaninants in the $F_{2}$ and $F_{3}$ generations. Because our study of radiation effects was only for a single generation, no conclusions can be drawn as to possible accommodation by subsequent generations or to the response of populations to continuous exposure to low levels of radiation.

There are few data on chronic radiation effects on invertebrates that can be compared to those reported here on $\mathrm{N}$. arenaceodentata. However, it is apparent from the data available on fish and invertebrates that the overall effects on reproductive success are dependent upon a number of factors. Important among these are reproductive strategy and sensitivity of stages in gametogenesis and in early development. It wauld be expected that species most vulnerable to chronic exposures to low levels of mutagenic contaminants are those that have a low fecundity and have highly sensitive stages. Because the results from our study indicate that in some invertebrates the range of sensitivity may overlap with that for fish and even for mamals and because the data base on effects of chronic low-level exposures is limited, it may not be overly conservative to adopt limits for the chronic exposure of low-fecundity aquatic animals based on the extensive data base available on the responses of mammals.

\section{ACKNOHLEDGMENTS}

Special thanks are given to Roger Martinelli, Marie Kalinowski, and Sue Tehensky who assisted in the laboratory. We also wish tc thank our project officer Marilyn Varela and others who provided critical reviews of the manuscript.

This work was supported by the U.S. Environmental Protection Agency, Office of Radiation Programs (DOE-EPA Interagency Agreement . $\mathrm{N}$ 89930414-01-1) and was performed under the auspices of the U.S. Department of Energy by Lawrence Livermore National Laboratory (Contract W-7405-ENG-48). 


\section{REFERENCES}

Anderson, S.L., and F.L. Harrison (1986), "Effects of Radiation on Aquatic Organisms and Radiobiological Methodologies for Effects Assessment," EPA 520/1-85-016 (U.S. Environmental Protection Agency, Washington, OC), $128 \mathrm{pp}$.

Anderson, S.L., F.L. Harrison, G. Chan, and D.H. Moore II (1987), "Chromosomal Aberrations, Reproductive Success, Life Span, and Mortality in Irradiated Neanthes arenaceodentata (Polychaeta)," EPA 520-1-87-007 (U.S. Environmental irotection Agency, Washington, $\mathrm{DC}), 55 \mathrm{pp}$.

Blaylock, B.G., and J.R. Trabaika (1978), "Evaluating the Effects of Ionizing Radiation on Aquatic Orgarisms," in Advances in Radiation Biology, Vol. 7 , J.T. Lett and H. Adler, Eds. (Academic Press, New York, NY), pp. 103-152.

Bonham, K., and L.R. Donaldson (1972), "Sex Ratios and Retardation of Conadal Qevelopment in Chronically Camma-Irradiated Chinook Salmon Smoits." Trans. Am. Fish. Soc. 101, 428-434.

Cervini, A., and S. Giavelli (1965), "Radiosensitivity of Different Meiotic Stages of Docytes in Parthenogenetic Dipioid Artemia salina Leach," Mutat. Res. 2. 452-456.

Chipman, W.A. (1972), "Ionizing Radiation," in Marine Ecology, Vol. I, Pt. 3, Ch. 11, 0. Kinne, Ed. (John Wiley/Interscience, New York, NY), pp. 1579-1657.

Cooley, J.L. (1973), "Effects of Chronic Environmental Radiation on a Natural Population of the Aquatic Snail Physa heterostropha, "Radiat. Res. 54, i30-i400.

Cooley, J.L., and F.L. Miller, Jr. (1971), "Effects of Chronic Irradiation on Laboratory Populations of the Aquatic Snail Physa heterostropha," Radiat. Res. 47. $716-724$.

Cosgrove, G.E., and a.G. Blaylock (1973), "Acute and Chronic Irradiation Effects in Mosquitofish at 15 or $25^{\circ} \mathrm{C}$," in Radionuclides in Ecosystems, Vol. 1, 0.J. Nelson, Ed. (U.S. Atomic Energy Commission, Washington, DC), pD. $579-584$.

Dobson, R.L., T.C. Kwan, and T. Straume (1984), "Tritium Effects on Germ Cells and Fertility," in Proceedings of European Seminar on Risks from Tritium Exposure, G. Gerber and C. Myttanaere, Eds. (Commission of the European Communities, Luxenbour ?), pp. 285-296.

Eobson, R.L., T.C. Kwan, B.F. Brunchkhorst, and T. Straume (1986), "Diminished Lifetime Reproductive Capacity in the Female following Early Radiation Exposure," in Life-Span Radiation Effects Studies in Animals: What Can They Tell Us? R.C. Thompson and J.A. Mahaffey, Eds. CoNF-830951 (U.S. Department of Energy, Washington, DC), pp. 281-294.

Egami, N., and K.-I. Ijiri (1979). "Effects of Irradiation on Germ Cells and Emb-yonic Development in Teleosts." Int. Rev. Cytol. 59, 195-248. 
Greenberger, J.S., J. Pechenik, A. Lord, L. Gould, E. Naperstek, K. Kase, and T.J. FitzGerald (1986). "X-Irradiation Effects on Growth and Metamorphos is of Gastropod Larvae (Crepidula fornicata): A Model for Environmental Radiation Teratogenesis," Arch. Environ. Contam. Toxicol. 15. 227-234.

Harrison, F.L., and S.A. Anderson (1988). "The Effects of Acute Radiation on Reproductive Success of the Polychaete Worm Neanthes arenaceodentata, "EPA 520/1-88-003 (U.S. Enviromental Protection Agency, Washington, DC), 21 pp.

Harrison, F.L., D.W. Rice, Jr., D.H. Moore, and M. Varela (1986), "Effects of Radiation on Frequency of Chromosomal Aberrations and Sister Chromatid Exchange in the Benthic Worm Neanthes arenaceodentata," in Wastes in the Ocean: Biolagical Effects of Waste Disposal, Volume? (Robert E. Krieger, Malabar, FL).

Hoppenheit, M. (1973). "Effects of Fecundity and Fertility of Single Sub-Lethal X-Irradiation of Gammarus duebeni Females," in Proc. Symp. Radioactive Contamination of the Marine Environment (International Atomic Energy Agency, Vienna), pp. 479-486.

Hyodo-Taguchi, Y., and N. Egami (1977), "Oamage to Spermatogenesis in Fish Kept in Tritiated Water," Radiat. Res. 71, 641-652.

Hyodo-Taguchi, Y. (1980), "Effects of Chronic Y-Irradiation on Spermatogenesis in the Fish, Oryzias latipes, with Special Reference to Regeneration of Testicular Stem Cells," in Radiation Effects on Aquatic Organisms, N. Egami, Ed. (Japan Scientific Societies Press, Tokyo; University Park Press, Baltimore, MD), pp. 91-104.

National Research Council, Committee on the Biologi al Effects of Ionizing Radiations (1980), The Effects on Populations of Exposure to Low Levels of Ionizing Radiation: 1980 (National Acadeny Press, Washington, DC).

Ophel, I.L. (1976), "Effects of Ionizing Radiation on Aquatic Organisms," in Effects of Ionizing Radiation on Aquatic Organisms and Ecosystems, Technical Report Series 172 (International Atomic Energy Agency, Vienna), pp. 57-88.

Oshida, P., C.S. Ward, and A. Mearns (1981), "Effects of Hexavalent and Trivalent Chromium on the Reproduction of Neanthes arenaceodentata (Polychaeta)," Mar. Environ. Res. 5, 41-49.

Oshida, P., and C.5. Ward (1982), "Bioaccumulaticn of Chromium and its Effects on the Reproduction of Neanthes arenaceodentata (Polychaeta)," Mar. Environ. Res. 2. 167-174.

Polikarpov, G.G. (1966), Radioecology of Aquatic Organisms (Reinhold, New York, AY), $210 \mathrm{pp}$.

Rachham, B.D., and D.S. Woodhead (1984), "Effects of Chronic Y-Irradiation on the Condds of Adult Arneca splendens (Osteichthyes:Teleostei)," Int. J. Radiat. Biol. 45, 645-656.

Ravera, 0. (1967). "The Effect of X-Rays on the Demographic Characteristics of Physa acuta (Gastropoda: Basonumatophora)." Malacologia 5, 95-109. 
Reish. 0.J. (1974), "The Establishment of Laboratory Colonies of Polychaetous Annelids," Thalassia Jugosl. 10, 181-195.

Rossi, S.S., and J.W. Anderson (1978), "Effects of No. 2 Fuel Oil-WaterSolubie-fractions on Growth and Reproduction in Neanthes arenaceodentata (Polychaeta:annelida)." Water Air Soil Pollut. 9. i55-170.

Snedecor, G.W., and W.G. Cochran (1967), Statistical Methods (The Iowa State University Press, Ames, Iowa, 6th Ed.), 593 pp.

Straume, T., R.L. Dobson, and T.C. Kwan (1997), "Neutron RBE and the Radiosensitive Target for Mouse Immature Oocyte Killing," Radiat. Res. 111 , $47-57$.

Straume, T., R.L. Dobson, and T.C. Kwan (1988), "Size of Lethallty Target in Mouse Immature Oocytes Determined with Accelerated Heavy Ions. Radiat. Env. Biophys. (in press).

Templeton, W.L. (1976), "Effects of Ionizing Radiation on Aquatic Populations and Ecosystems," Technical Report Series 172 (International Atomic Energy Agency, Vienna), pp. 89-119.

Templeton, W.L., R.E. Nakatani, and E.E. Held (1971), "Radiation Effects," in Radioactivity in the Marine Environment (National Academy of Sciences, Washington, DC), pp. 223-239.

Trabalka, J.R., and C. P. Allen (1977), "Aspects of Fitness of a Mosquitofish Gambusia affinis Population Exposed to Chronic Low-Level Environmental Radiation," Radiat. Res. 70. 198-211.

United Nations Scientific Committee on the Effects of Atomic Radiation (1977). Sources and Effects of Ionizing Radiation, E.77.IX.l (United Nations Publications, New York, NY).

United Nations Scientific Committee on the Effects of Atomic Radiation (1982), Ionizing Radiation: Sources and Biological Effects, E.82.IX.8 (United Nations Publications, New York, NY).

United Nations Scientific Committee on the Effects of Atomic Radiation (1986), Genetic and Somatic Effects of Ionizing Radiation, E.86.IX.9 (United Nations Publications, New Yoik, NY).

Welander, A.D., L.R. Donaldson, R.F. Foster, K. Bonham, and A.H. Seymour (1948). "The Effects of Roentgen Rays on the Embryos and Larvae of the Chinook Salmon," Growth 12, 203-242.

Woodhead, D.S. (1977), "The Effects of Chronic Irradiation on the Breeding Performance of the Guppy, Poecilia reticulata (Osteichthyes: Teleostei)," Int. J. Radiat. Biol. 32,1 .

Woodhead, D.W. (1984), "Contamination Due to Radioactive Materials," in Marine Ecology, Vol. V, Part 3, O. Kinne, Ed. (John Wiley and Sons, Ltd., Chichester, UK), pp. 1287-1618. 
APPENDLX

Data Base from the Experiment to Determine the Effects of Chronic Radiation on Reproductive Success of Neanthes areqnaceodentata 
Taole A-1. Experimental data from Neanthes arenacgodentafa mated pairs that were not irradiated with an external gamaradiation source (controls). The number of days from spawn to hatch and from hatch $t$ 's 5 dwn as well as the estimated hatch number are provided.

\begin{tabular}{|c|c|c|c|c|c|c|c|c|c|c|c|c|}
\hline $\begin{array}{l}P_{1} \begin{array}{c}\text { Spawn } \\
\text { to }\end{array} \\
F_{\text {, hatch }} \\
\text { (days) }\end{array}$ & $\begin{array}{l}F_{1} \\
F_{1}\end{array}$ & $\begin{array}{l}\text { Hatch } \\
\text { to } \\
\text { spawn } \\
\text { (days }\end{array}$ & ID & $\begin{array}{l}\text { Spawn } \\
\text { number }\end{array}$ & $\begin{array}{c}\text { Live } \\
\text { number }\end{array}$ & $\begin{array}{l}\text { Live } \\
(x)\end{array}$ & $\begin{array}{l}\text { Dying } \\
\text { number }\end{array}$ & $\begin{array}{c}\text { Dead } \\
\text { number }\end{array}$ & $\begin{array}{l}\text { Dead } \\
(z)\end{array}$ & $\begin{array}{l}\text { Aunormal } \\
\text { number }\end{array}$ & $\begin{array}{c}\text { Est } \\
\text { hatch } \\
\text { number }\end{array}$ & Comments \\
\hline 12 & & 119 & $8-2-7$ & 73 & 57 & 78.1 & 16 & 0 & 0 & 5 & 57 & $\operatorname{Can}{ }^{a}$ \\
\hline 12 & & 125 & $8-2-2$ & 226 & 213 & 94.2 & 川 & 2 & 0.9 & 60 & 166 & Can \\
\hline 12 & & 129 & $8-2-3$ & 452 & 434 & 96.0 & וו & 7 & 3.6 & 2 & 434 & Can \\
\hline 12 & & 129 & $8-2-6$ & 103 & 101 & 98.1 & 2 & 0 & 0 & 15 & 88 & \\
\hline 12 & & 128 & $6-2-10$ & 307 & 304 & 99.0 & i & $z$ & 0.7 & 62 & 245 & \\
\hline 12 & & 119 & $8-2-10 b$ & 91 & 91 & 100 & o & 0 & 0 & 1 & 90 & Hatch b \\
\hline 12 & & 134 & $8-2-16$ & 361 & 357 & 98.9 & 2 & 2 & 0.6 & 21 & 340 & \\
\hline 12 & & 128 & $8-2-32$ & 202 & 200 & 99.0 & $\mathbf{0}$ & 2 & 1.0 & 15 & 187 & \\
\hline 12 & & 134 & $8-2-36$ & 202 & 202 & 100 & 0 & 0 & 0 & 18 & 184 & \\
\hline 12 & & 122 & $8-2-37$ & 96 & 93 & 96.9 & 2 & 1 & 1.0 & 3 & 93 & \\
\hline 12 & & 121 & $8-2-42$ & 230 & 205 & B9. 1 & 20 & 5 & 2.2 & 24 & 205 & \\
\hline 12 & & 121 & $8-2-49$ & 115 & 112 & 97.4 & 3 & 0 & 0 & 10 & 105 & \\
\hline 12 & & 152 & $8-2-52$ & 38 & 34 & 89.5 & 2 & 2 & 5.3 & 0 & 34 & Can \\
\hline 12 & & 119 & $8-2-53$ & 89 & 74 & 84.1 & 14 & 0 & 0 & 11 & 74 & Can \\
\hline 12 & & 149 & $8-2-55$ & 327 & 325 & 99.4 & $\mathbf{I}$ & 1 & 0.3 & 22 & 305 & \\
\hline 12 & & 136 & $8-2-56$ & 121 & 121 & 100 & 0 & 0 & D & 0 & 121 & $S c a t$ \\
\hline 12 & & 128 & $8-2-60$ & 223 & 203 & 91.0 & 17 & 3 & 1.4 & 40 & 183 & \\
\hline 12 & & 121 & $8-2-63$ & 16.5 & 157 & 95.2 & 2 & 6 & 3.6 & 16 & 149 & \\
\hline 12 & & 134 & $8-2-66$ & 305 & 305 & 99.7 & 0 & 1 & 0.3 & 25 & 281 & \\
\hline 12 & & 125 & $8-2-68$ & 196 & 185 & 94.4 & 5 & 6 & 3.1 & 52 & 144 & \\
\hline 12 & & 119 & $8-2-74 a$ & 218 & 217 & 99.5 & 1 & 0 & 0 & 18 & 200 & \\
\hline 12 & & 125 & $8 \cdot 2-74 b$ & 239 & 229 & 95.8 & $\mathrm{~B}$ & 2 & 0.8 & 47 & 192 & \\
\hline 12 & & 124 & $8-2-75$ & 209 & 205 & $9 \mathrm{~B}, 1$ & 3 & 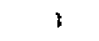 & 0.5 & 2) & 188 & \\
\hline 12 & & 120 & $8-2-77 a$ & 11 & 98 & 88.3 & 12 & $i$ & 0.9 & 21 & 90 & \\
\hline 12 & & 125 & $8-2-80$ & 96 & 83 & 86.5 & 13 & 0 & 0 & 16 & 80 & \\
\hline 12 & & 120 & $6-2-88$ & 89 & 72 & 80.9 & 17 & 0 & 0 & 0 & 72 & \\
\hline
\end{tabular}


Table A-I (cont.)

\begin{tabular}{|c|c|c|c|c|c|c|c|c|c|c|c|c|}
\hline & 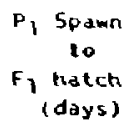 & $\begin{array}{l}\text { Fy Hatch } \\
\text { lo } \\
\text { F, spawn } \\
\text { (days) }\end{array}$ & ID & $\begin{array}{l}\text { Spawn } \\
\text { number }\end{array}$ & $\begin{array}{c}\text { Live } \\
\text { number }\end{array}$ & $\begin{array}{l}\text { Live } \\
(x)\end{array}$ & $\begin{array}{l}\text { Dying } \\
\text { number }\end{array}$ & $\begin{array}{l}\text { Dead } \\
\text { number }\end{array}$ & $\begin{array}{l}\text { Dedd } \\
\text { (z) }\end{array}$ & $\begin{array}{l}\text { Atnornal } \\
\text { number }\end{array}$ & $\begin{array}{l}\text { Est } \\
\text { hatch } \\
\text { number }\end{array}$ & Comments \\
\hline & 13 & 126 & $15-4-3$ & 311 & 302 & 97.2 & 2 & 7 & 2.2 & $y$ & 302 & \\
\hline & 13 & 341 & $15-4-4$ & 318 & $22 B$ & 71.7 & 21 & 69 & 21.7 & 122 & 196 & Abadr's \\
\hline & 13 & 125 & $15-4-5$ & 303 & 288 & 95.0 & 15 & 0 & 0 & 108 & 195 & \\
\hline & 13 & 124 & $15-4-6$ & 257 & 250 & 97.3 & 6 & $\mathbf{3}$ & 0.4 & 63 & 194 & \\
\hline & 13 & 125 & $15-4-7$ & 220 & 208 & 94.6 & 9 & 3 & 1.4 & 42 & 178 & \\
\hline & 13 & 138 & $15-4-13$ & 506 & 457 & 90.3 & 36 & 13 & 2.6 & 121 & 385 & \\
\hline & 13 & 125 & $15-4-22$ & 325 & 316 & 9.2 & 2 & 7 & 0.2 & 7 & 316 & \\
\hline & 13 & 142 & $15-4-23$ & 389 & 336 & 86.4 & 37 & 16 & 4.1 & 84 & 305 & \\
\hline & 13 & 119 & $15-4-25$ & 160 & 152 & 95.0 & 5 & 3 & 1.9 & 13 & 147 & \\
\hline & 13 & 125 & $15-4-32$ & 325 & $\therefore 16$ & 97.2 & 2 & 7 & 2.2 & $\mathbf{0}$ & 316 & \\
\hline$x$ & 13 & 121 & $15-4-32 a$ & 167 & 159 & 95.2 & 6 & 2 & 1.2 & 29 & 138 & \\
\hline & 13 & 123 & $(5-4-3)$ & 225 & 221 & 98.2 & 3 & 1 & 0.4 & 28 & 197 & \\
\hline & 13 & 137 & $15-4-40$ & 533 & 512 & 96.1 & 15 & 6 & 1.1 & 166 & 367 & \\
\hline & 13 & 119 & $15-4-50$ & 125 & 26 & 20.8 & 81 & 18 & 14.4 & 3 & 26 & $5 c d t$ \\
\hline & 13 & 124 & $15-4-53$ & 253 & 251 & 99.2 & 1 & 1 & 0.4 & 5 & 248 & \\
\hline & 13 & 117 & $15-4-54$ & 106 & 98 & 92.5 & 8 & 0 & 0 & 6 & 98 & \\
\hline & 13 & 133 & $15-4-55$ & 221 & 218 & 98.6 & 1 & 2 & 0.9 & 32 & 189 & \\
\hline & 13 & 117 & $16-1-1$ & 163 & 149 & 91.4 & 14 & 0 & 0 & 6 & 149 & Can \\
\hline & 13 & 143 & $16-1-2$ & 158 & 150 & 94.9 & 6 & 2 & 1.3 & 20 & 138 & $\operatorname{Can}$ \\
\hline & 13 & 126 & $26-1-3$ & 208 & 203 & 97.6 & 4 & $i$ & 0.5 & 48 & 160 & \\
\hline & 13 & 113 & $16-1-4$ & 116 & 115 & 99.1 & 1 & 0 & 0 & 6 & 110 & Carr \\
\hline & 13 & 134 & $15-1-8$ & 200 & 197 & 98.5 & 0 & 3 & 1.5 & 3 & 197 & \\
\hline & 13 & 125 & $16-1=9$ & 255 & 251 & 98.4 & 3 & 1 & 0.4 & 5 & 250 & \\
\hline & 13 & 725 & $16-1-38 b$ & 34 & 300 & 96.5 & 7 & 4 & 1.3 & 40 & 271 & \\
\hline & 13 & 129 & $16-1-19$ & נוב3 & 276 & 88.8 & 32 & 3 & .. 0 & 115 & 196 & \\
\hline & 13 & $\$ 17$ & $16-1-20$ & 161 & 122 & 75.8 & 39 & 0 & 0 & 17 & 122 & \\
\hline
\end{tabular}


Jable A-1 (cont .)

\begin{tabular}{|c|c|c|c|c|c|c|c|c|c|c|c|}
\hline $\begin{array}{l}\text { P1 Spawn } \\
\text { to } \\
\text { f, hatch } \\
\text { (days) }\end{array}$ & $\begin{array}{l}\text { F) Hatch } \\
\text { to } \\
\text { f) spawn } \\
\text { tolays }\end{array}$ & I0 & $\begin{array}{l}\text { Spawn } \\
\text { number }\end{array}$ & $\begin{array}{l}\text { Live } \\
\text { number }\end{array}$ & $\begin{array}{l}\text { Live } \\
\{3\}\end{array}$ & $\begin{array}{l}\text { Dying } \\
\text { sumber }\end{array}$ & $\begin{array}{l}\text { Dead } \\
\text { number }\end{array}$ & $\begin{array}{l}\text { Dead } \\
(x)\end{array}$ & $\begin{array}{c}\text { Abnormal } \\
\text { number }\end{array}$ & $\begin{array}{l}\text { Est. } \\
\text { hatch } \\
\text { number }\end{array}$ & Cuments \\
\hline 13 & 129 & $17-5-1$ & 322 & 312 & 96.9 & B & 2 & 0.6 & 29 & 293 & \\
\hline 13 & $1<5$ & $17-5-6$ & 216 & 214 & 99.1 & 1 & 1 & 0.5 & 9 & 207 & \\
\hline 13 & 140 & $17-5-8$ & 637 & 607 & 95.3 & 23 & y & 1.1 & 18 & 607 & \\
\hline 13 & 121 & $17-5-74 a$ & 123 & 121 & 98.4 & 1 & 1 & 0.8 & 15 & 108 & \\
\hline 13 & 134 & $17-5-14 b$ & 429 & 426 & 99.3 & 2 & 1 & 0.2 & 22 & 407 & \\
\hline 13 & 136 & $17-5-15$ & 298 & 294 & 98.7 & 3 & 1 & 0.3 & 26 & 272 & \\
\hline 13 & 123 & $17-5-17$ & 288 & 152 & 52.8 & 32 & 104 & 36.1 & 112 & 152 & Aban \\
\hline 13 & 135 & $17-5-33$ & 297 & 297 & 100 & 0 & 0 & 0 & 10 & 287 & \\
\hline 13 & 123 & $17-5-34$ & 209 & 189 & 90.4 & 20 & 0 & 0 & 36 & 173 & can \\
\hline 13 & 147 & $17-5-37$ & 178 & 154 & 86.5 & 20 & $A$ & 2.2 & 19 & 154 & Atan \\
\hline 13 & L & $17-5-38$ & 125 & 0 & 0 & 0 & 125 & 100 & 0 & D & \\
\hline 13 & 137 & $17-5-41$ & 495 & 474 & 95.8 & 16 & 5 & 1.0 & 113 & 382 & \\
\hline 13 & 139 & $17-5-44$ & 173 & 171 & $9 B . B$ & 2 & 0 & 0 & 9 & 164 & \\
\hline 13 & 126 & $17-5-45$ & 265 & 259 & 97.7 & 6 & 0 & 0 & 33 & 232 & \\
\hline 13 & 123 & $17-5-49$ & 227 & $20 B$ & 91.6 & 13 & 6 & 2.6 & 53 & 174 & \\
\hline 11 & 165 & $22-7-5$ & 282 & 253 & 89.7 & 2) & 8 & 2.8 & 33 & 249 & \\
\hline 11 & 167 & $22-7-10 \mathbf{d}$ & 209 & 35 & 16.8 & 143 & 31 & 14.8 & 184 & 25 & \\
\hline 11 & 155 & $22-7-14$ & 6 & 0 & 0 & 4 & 2 & 33.3 & 1 & 0 & $C_{d n}$ \\
\hline ו I & 172 & $22-7-15$ & 399 & 3.68 & 92.2 & 28 & 3 & 0.8 & 3 & 368 & Hatch \\
\hline 11 & 172 & $22-7-17$ & 229 & 217 & 94.8 & 12 & o & 0 & 0 & 217 & llatch \\
\hline 11 & 112 & $22-7-41$ & 338 & 75 & 22.2 & 175 & 88 & 26 & 338 & 0 & Scat \\
\hline 11 & 154 & $22-7-43$ & 189 & 180 & 95.2 & 5 & 4 & 2.1 & 21 & 108 & Can \\
\hline 11 & 165 & $22-7-54$ & 368 & 273 & 74.2 & 67 & 28 & 7.6 & 203 & 165. & \\
\hline
\end{tabular}


Iable A-I (cont.)

\begin{tabular}{|c|c|c|c|c|c|c|c|c|c|c|c|}
\hline $\begin{array}{l}\text { P1 Spawn } \\
\text { to } \\
\text { F1 naten } \\
\text { (days) }\end{array}$ & $\begin{array}{c}F_{1} \text { Hatch } \\
\text { to } \\
F_{1} \text { spawn } \\
\text { (days) }\end{array}$ & ID & $\begin{array}{l}\text { Spawn } \\
\text { number }\end{array}$ & $\begin{array}{l}\text { Live } \\
\text { number }\end{array}$ & $\begin{array}{l}\text { Live } \\
\text { (x) }\end{array}$ & $\begin{array}{l}\text { Dying } \\
\text { number }\end{array}$ & $\begin{array}{c}\text { Dead } \\
\text { number }\end{array}$ & $\begin{array}{l}\text { Dead } \\
(z)\end{array}$ & $\begin{array}{l}\text { Abnormal } \\
\text { number }\end{array}$ & $\begin{array}{l}\text { Est. } \\
\text { hatch } \\
\text { number }\end{array}$ & Comments \\
\hline 12 & 118 & $24-3-3 x$ & 445 & 419 & 94.2 & 26 & $c$ & 0 & 103 & 342 & \\
\hline 12 & 119 & $24-3-4 a$ & 367 & 360 & 98.1 & 4 & 3 & 0.8 & 30 & 337 & \\
\hline 12 & 1 & $24-3-4 b$ & 309 & 248 & 80.3 & 35 & 26 & e. 4 & 7 & 248 & $\operatorname{can}$ \\
\hline 12 & 116 & $24-3-14$ & 430 & 396 & 92.1 & 25 & 9 & 2.1 & 39 & 391 & \\
\hline 12 & 112 & $24-3-18$ & 77 & 77 & 100 & 0 & 0 & 0 & 3 & 74 & Can, scat \\
\hline 12 & 125 & $24-3-23 a$ & 279 & 278 & 99.6 & 1 & 0 & D & 1 & 278 & \\
\hline 12 & 125 & $24-3-23 b$ & 158 & 157 & 99.4 & 1 & 0 & 0 & 1 & 157 & \\
\hline 12 & 121 & $24-3-25$ & 131 & 129 & 98.5 & 0 & 2 & 1.5 & 16 & 115 & \\
\hline 12 & 113 & $24-3-30$ & 304 & 275 & 90.5 & 26 & 3 & 1.0 & 88 & 216 & \\
\hline 12 & 120 & $24-3-36$ & 168 & 167 & 99.4 & 1 & 0 & 0 & 10 & 158 & \\
\hline 12 & 120 & $24-3-43$ & 309 & 308 & 99.7 & 1 & 0 & 0 & 7 & 302 & Can \\
\hline 12 & 110 & $24-3-45$ & 192 & 181 & 94.3 & 11 & 0 & 0 & 0 & 181 & \\
\hline 12 & 118 & $24-3-46$ & 309 & 248 & 80.3 & 35 & 26 & 8.9 & 53 & 248 & \\
\hline 12 & 119 & $24-3-50$ & 298 & 294 & 98.7 & 1 & 3 & 1.0 & 32 & 266 & \\
\hline 12 & 111 & $24-3-54$ & 253 & 241 & 95.3 & 10 & 2 & 0.8 & 31 & 222 & Can \\
\hline 12 & 103 & $24-3-56 a$ & 67 & 35 & 52.2 & 11 & 21 & 31.3 & 28 & 35 & $\operatorname{can}$ \\
\hline 12 & 103 & $24-3-56 b$ & 152 & 152 & 100 & 0 & 0 & D & 0 & 152 & Hatch \\
\hline 12 & 103 & $24-3-57$ & 82 & 38 & 46.3 & 20 & 24 & 29.3 & 12 & 38 & aban \\
\hline
\end{tabular}

a Can, male eating developing entryos.

b Hatch, embryos hatched into larvae.

c Seat, brood scathered throughout tube

d Aban, male abandoned the broad.

e L original data sheet lost. 
Idbie A-2. Experimental data from Neanthes arenacegodentala mated pairs that were exposed to 0.19 mby/h from an external ganmiradiation source. The number of days from spawn to hatch and from hatch to spawn as well as the estimated hatch number

are provided. 
table A-2. (cont.)

\begin{tabular}{|c|c|c|c|c|c|c|c|c|c|c|c|}
\hline $\begin{array}{l}\text { P1 Spawn } \\
\text { to } \\
\text { f, hates } \\
\text { (days) }\end{array}$ & $\begin{array}{l}\text { Fi Hatch } \\
\text { to } \\
\text { Fy spaun } \\
\text { (days) }\end{array}$ & ID & $\begin{array}{l}\text { Spawn } \\
\text { number }\end{array}$ & $\begin{array}{l}\text { Live } \\
\text { number }\end{array}$ & $\begin{array}{l}\text { Live } \\
(x)\end{array}$ & $\begin{array}{l}\text { Dying } \\
\text { number }\end{array}$ & $\begin{array}{l}\text { Dead } \\
\text { number }\end{array}$ & $\begin{array}{l}\text { Dead } \\
(x)\end{array}$ & $\begin{array}{c}\text { Atnormal } \\
\text { number }\end{array}$ & $\begin{array}{l}\text { Est. } \\
\text { hatch } \\
\text { number }\end{array}$ & Comments \\
\hline 10 & 108 & $25-3-45$ & 194 & 194 & 100 & 0 & 0 & 0 & 4 & 190 & \\
\hline 10 & 109 & $25-3-47$ & 232 & 209 & 90.1 & 22 & 1 & 0.4 & 26 & 206 & Can \\
\hline 10 & 132 & $25-3-48$ & 221 & 183 & 82.8 & 28 & 10 & 4.5 & 138 & 83 & Can \\
\hline 10 & 110 & $26-4-3$ & 231 & 224 & 97.0 & 6 & 1 & 0.4 & 13 & 218 & tan \\
\hline 10 & 114 & $26-4-5$ & 132 & 127 & 96.2 & 2 & 3 & 2.3 & 19 & 113 & \\
\hline 10 & 119 & $26-4-7 a$ & 192 & 181 & 94.3 & 6 & 5 & 2.6 & 57 & 135 & \\
\hline 10 & 133 & $26-4-7 b$ & 178 & 128 & 71.9 & 39 & 11 & 6.2 & 65 & 113 & \\
\hline 10 & 108 & $26-4-10$ & 227 & 227 & 100 & 0 & 0 & 0 & 0 & 227 & Hatch \\
\hline 10 & 129 & $26-4-13$ & 289 & 243 & 84.1 & 24 & 22 & 7.6 & 77 & 212 & \\
\hline 10 & 125 & $26-4-18$ & 315 & 287 & 91.1 & 23 & 5 & 1.6 & 164 & 151 & \\
\hline 10 & 108 & $26-4-20 a$ & 152 & 107 & 70.4 & 45 & 0 & $\mathbf{0}$ & 11 & 107 & Can \\
\hline 10 & 125 & $26-4-23 a$ & 392 & 17 & 4.3 & 169 & 206 & 52.6 & 256 & 17 & \\
\hline 10 & 125 & $26-4-23 b$ & 83 & 27 & 32.5 & 12 & 44 & 53.0 & 80 & 3 & \\
\hline 10 & 107 & $26-4-27$ & 281 & 180 & 99.4 & 0 & 1 & 0.6 & 1 & 180 & Hatch \\
\hline to & 112 & $26-4-30$ & 21 & 21 & 100 & o & 0 & 0 & 0 & 21 & Hatch \\
\hline 10 & 125 & $26-4-33$ & 271 & 253 & 93.4 & 16 & 2 & 0.7 & 140 & 131 & Can \\
\hline 20 & 151 & $26-4-34 b$ & 234 & 75 & 32.1 & 72 & 87 & 37.2 & 80 & 75 & \\
\hline 10 & 128 & $26-4-35$ & 187 & 156 & 83.4 & 15 & 16 & B. 6 & 2 & 156 & \\
\hline 10 & 101 & $26-4-38 a$ & 304 & 303 & 99.7 & 0 & 1 & 0.3 & 12 & 292 & \\
\hline 10 & 108 & $26-4-40$ & 190 & 190 & 100 & 0 & D & D & 0 & 190 & Hateh \\
\hline 32 & $12 B$ & $27-5-1$ & 322 & 258 & 80.1 & 52 & 12 & 3.7 & $8 B$ & 234 & \\
\hline 12 & 105 & $27-5-3$ & 203 & 198 & 97.5 & 2 & 3 & 1.5 & 5 & 198 & Hatch \\
\hline 12 & 107 & $27-5-4$ & 185 & 785 & 100 & 0 & 0 & 0 & 23 & 162 & - Can \\
\hline 12 & 105 & $27-5-7$ & 116 & 116 & 100 & D & 0 & 0 & 0 & 116 & Hatch \\
\hline 12 & 118 & $27-5-9$ & 405 & $33 i$ & 81.7 & 52 & 22 & 5.4 & 363 & 42 & \\
\hline 12 & 110 & $27-5-13$ & 222 & 210 & 94.6 & 10 & 2 & 0.9 & 49 & 173 & $\operatorname{Can}$ \\
\hline 12 & 102 & $27-5-14$ & 207 & 185 & 89.4 & 22 & D & $D$ & 5 & 185 & \\
\hline 12 & 100 & $27-5-16$ & 182 & 174 & 95.6 & 7 & 1 & 0.5 & 13 & 169 & Hatch \\
\hline 12 & 107 & $27-5-20$ & 96 & 96 & 100 & 0 & $D$ & $\mathbf{D}$ & 0 & 96 & Hatch \\
\hline
\end{tabular}


Iable A-2 (cont.)

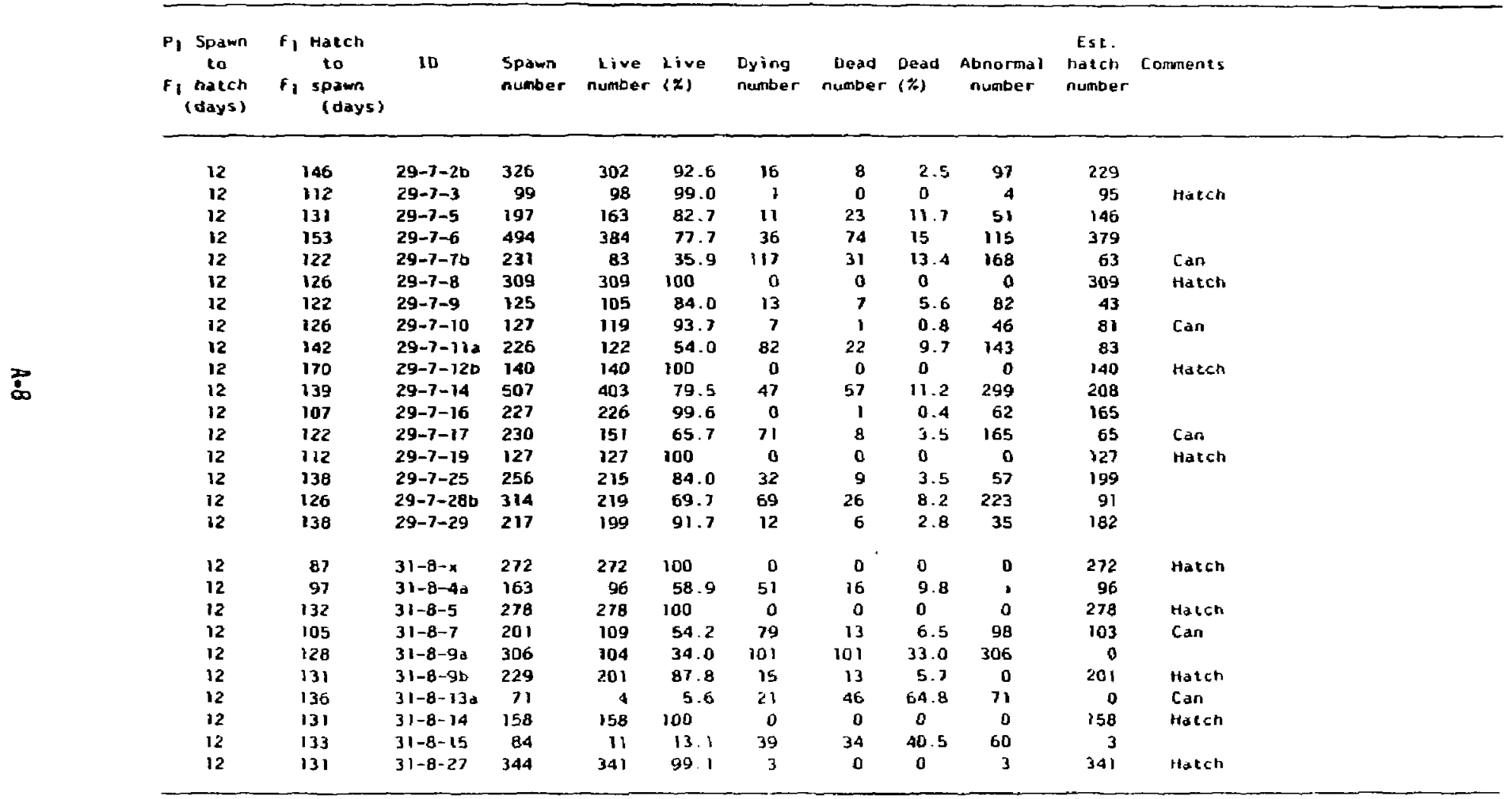

d Malch, enuryos halched into larvae.

- Can, male eating developing embryos. 
Table A-3. Experimental data from Neanthes arenaceodentata mated pairs that were exposed co $2.1 \mathrm{mEy} / \mathrm{h}$ from an external gammaradiation source. The number of days from spawn to hatch and from hatch to spawn as well as the estimated hatch number are provided.

\begin{tabular}{|c|c|c|c|c|c|c|c|c|c|c|c|}
\hline $\begin{array}{l}\text { P1 Spawn } \\
\text { to } \\
\text { F hateh } \\
\text { (days) }\end{array}$ & $\begin{array}{c}F_{1} \text { Hatch } \\
\text { to } \\
F_{1} \text { spawn } \\
\text { (days) }\end{array}$ & ID & $\begin{array}{l}\text { Spawn } \\
\text { number }\end{array}$ & $\begin{array}{l}\text { Live } \\
\text { number }\end{array}$ & $\begin{array}{l}\text { Live } \\
(z)\end{array}$ & $\begin{array}{l}\text { Dying } \\
\text { number }\end{array}$ & $\begin{array}{c}\text { Dead } \\
\text { number }\end{array}$ & $\begin{array}{l}\text { Dead } \\
(z)\end{array}$ & $\begin{array}{c}\text { Abnorma } 1 \\
\text { number }\end{array}$ & $\begin{array}{l}\text { Est. } \\
\text { hatch } \\
\text { number }\end{array}$ & Comments \\
\hline 12 & 115 & $11-4-1$ & 188 & 171 & 91.0 & 17 & 0 & 0 & 20 & 168 & $\operatorname{Can}^{2}$ \\
\hline 12 & 121 & $11-4-5$ & 116 & 0 & D & 103 & 13 & 11.2 & 55 & 0 & \\
\hline 12 & 127 & $11-4-8$ & 297 & 89 & $30-0$ & 157 & $5 i$ & 17.2 & 90 & 89 & $\operatorname{can}$ \\
\hline 12 & 119 & $11-4-11$ & 165 & 153 & 92.7 & 2 & 10 & 6.1 & 48 & 117 & \\
\hline 12 & 125 & $11-4-14 a$ & 113 & 43 & 38.1 & 57 & 13 & 11.5 & 53 & 43 & Can \\
\hline 12 & 119 & $11-4-16$ & 189 & 175 & 92.6 & 4 & 10 & 5.3 & 28 & 161 & \\
\hline 12 & 123 & $11-4-17$ & 189 & 58 & 30.7 & 96 & 35 & 18.5 & 78 & 58 & \\
\hline 12 & 123 & $31-4-22$ & 201 & 201 & 100 & 0 & 0 & 0 & 8 & 193 & Hatent \\
\hline 12 & 128 & $11-4-25$ & 212 & $: 04$ & 49.1 & 17 & 91 & 42.9 & 138 & 74 & \\
\hline 12 & 151 & $r-4-33$ & 478 & 319 & 66.7 & $10 \%$ & 50 & 10.5 & 177 & $30 i$ & \\
\hline 12 & 125 & $11-4-35$ & 62 & 29 & 46.8 & 8 & 25 & 40.3 & 31 & 29 & Can \\
\hline 12 & 118 & $11-4-45$ & 220 & 186 & 84.5 & 25 & 9 & 4.1 & 38 & 182 & \\
\hline 12 & 137 & $11-4-52$ & 181 & 100 & 55.2 & 34 & 47 & 26.0 & 110 & 71 & Abanc \\
\hline 12 & 125 & $11-4-53$ & 202 & 116 & 57.4 & 41 & 45 & 22.3 & 86 & 116 & Can \\
\hline 13 & 114 & $16-2-3$ & 256 & 245 & 95.7 & 10 & 1 & 0.4 & 11 & 245 & \\
\hline 13 & 123 & $16-2-7$ & 329 & 206 & 62.6 & 120 & 3 & 0.9 & 165 & 164 & \\
\hline 13 & 118 & $16-2-112$ & 248 & 78 & 31.8 & 132 & 38 & 15.3 & 127 & 78 & \\
\hline 13 & 123 & $16-2-11 b$ & 187 & 151 & BO. 7 & 21 & 15 & 8.0 & 120 & 67 & Can \\
\hline 13 & 125 & $16-2-14$ & 109 & 62 & 56.9 & 18 & 29 & 26.6 & 96 & 13 & \\
\hline 13 & 118 & $15-2-21$ & 132 & 121 & 92.1 & 4 & 7 & 5.3 & 61 & 71 & \\
\hline 13 & 121 & $16-2-23$ & $\mid 71$ & 108 & 63.2 & 13 & 50 & 29.2 & 79 & 92. & \\
\hline 13 & 113 & $16-2-34$ & 153 & 134 & $8: 0$ & 18 & 1 & 0.6 & $\mathbf{u}$ & 134 & \\
\hline 13 & 121 & $16-2-39$ & 227 & 209 & 92.1 & 11 & 7 & 3.1 & 12 & 155 & \\
\hline 13 & 125 & $16-2-41$ & 336 & 94 & 28.0 & 181 & וס & 18.2 & 213 & 94 & \\
\hline 13 & 120 & $\mid 6-2-51$ & 232 & 208 & 89.7 & 7 & 17 & 7.3 & 20 & 208 & \\
\hline 13 & 119 & $16-2-52$ & 219 & 185 & 84.5 & 10 & 24 & 11 & 30 & 185 & \\
\hline 13 & 115 & $16-2-53$ & 202 & 182 & 90.1 & 38 & 2 & , & 20 & 102 & \\
\hline 13 & 115 & $16-2-57$ & 205 & 198 & 96.0 & 7 & 0 & 0 & 13 & 192 & Can \\
\hline
\end{tabular}


Table A-3. (cont.)

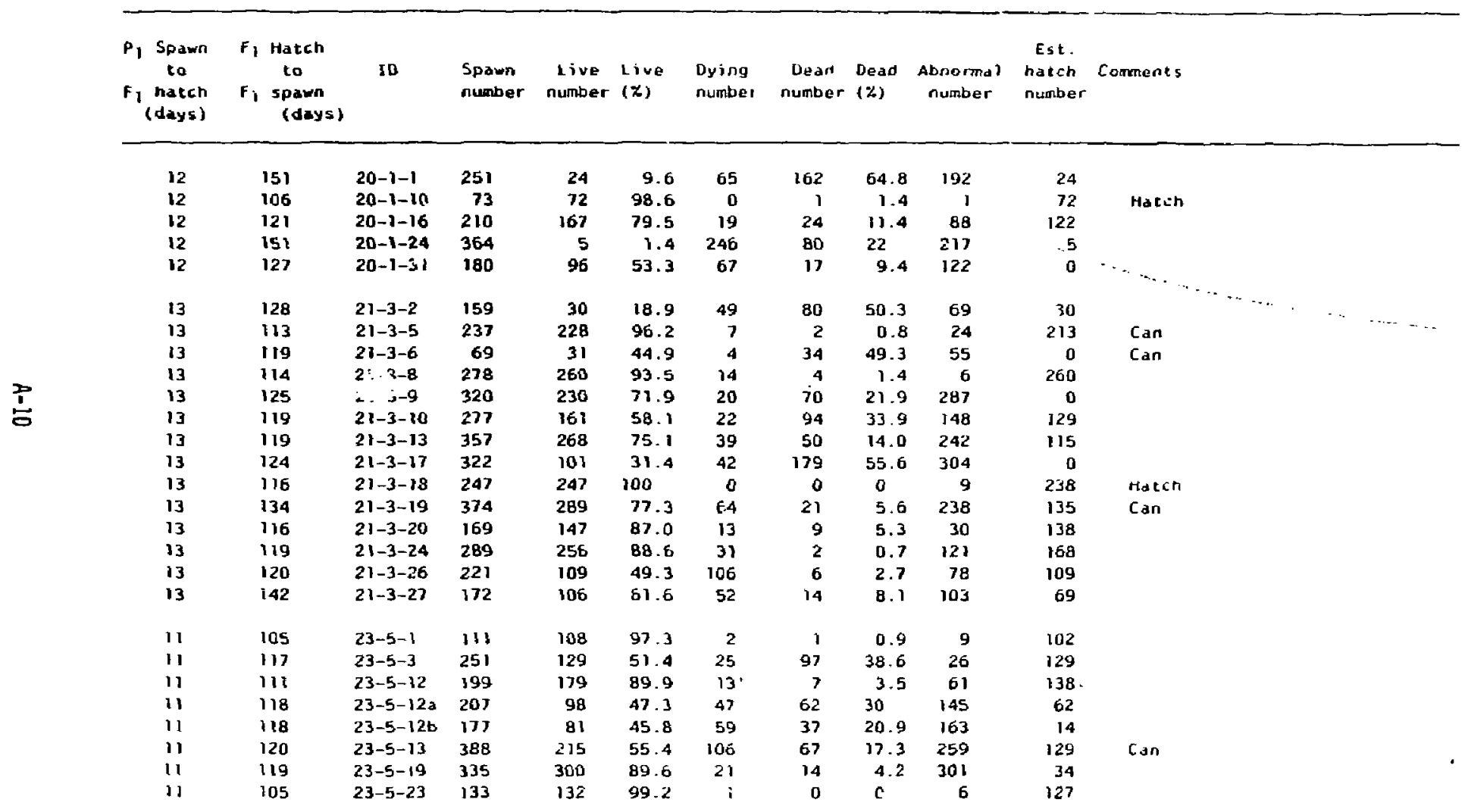


Jable A-3. (cont.)

\begin{tabular}{|c|c|c|c|c|c|c|c|c|c|c|c|c|}
\hline $\begin{array}{l}\text { Pr Spawn } \\
\text { to } \\
\text { F, hateh } \\
\text { (days) }\end{array}$ & $\begin{array}{l}F_{1} \text { Haten } \\
\text { to } \\
F_{1} \text { spawn } \\
(d a, 5)\end{array}$ & ID & $\begin{array}{l}\text { Spawn } \\
\text { number }\end{array}$ & $\begin{array}{l}\text { Live } \\
\text { number }\end{array}$ & $\begin{array}{l}\text { Live } \\
\text { (x) }\end{array}$ & $\begin{array}{l}\text { Dying } \\
\text { numiter }\end{array}$ & $\begin{array}{c}\text { Dear } \\
\text { number }\end{array}$ & $\begin{array}{l}\text { Dead } \\
(z)\end{array}$ & $\begin{array}{c}\text { Abnormal } \\
\text { number }\end{array}$ & $\begin{array}{l}\text { Est. } \\
\text { hatch } \\
\text { number }\end{array}$ & Ccaments & \\
\hline 12 & 128 & $24-6-2$ & 179 & 170 & 95.0 & 1 & 8 & 4.5 & 56 & 123 & Hatch & \\
\hline 12 & 99 & $24-6-5$ & 158 & 153 & 96.8 & 5 & 0 & 0 & 0 & 153 & & \\
\hline 12 & 108 & $24-6-B$ & 259 & 239 & 92.3 & 2 & 18 & 7 & 103 & 156 & Can & \\
\hline 12 & 109 & $24-6-13$ & 285 & 84 & 29.5 & $8 l$ & 120 & 42.1 & 266 & 19 & & \\
\hline 12 & 100 & $24-6-17$ & 188 & 155 & 82.4 & 33 & 0 & 0 & 17 & 155 & Can & \\
\hline 12 & 101 & $24-6-27$ & 268 & 266 & 99.3 & 2 & 0 & 0 & 33 & 235 & & \\
\hline 12 & 111 & $24-6-28 a$ & 107 & 99 & 59.3 & 56 & 12 & 7.2 & 90 & 77 & & \\
\hline 12 & 106 & $24-6-35 a$ & 252 & 229 & 90.9 & 13 & 10 & 4 & 31 & 221 & & \\
\hline 12 & 114 & $24-6-36$ & 302 & 221 & 73.2 & 52 & 29 & 9.6 & 209 & 93 & Can & \\
\hline 12 & 109 & $24-6-37$ & 282 & 232 & 82.3 & 39 & 11 & 3.9 & 174 & ros & & \\
\hline 12 & 105 & $24-6-39$ & 387 & 168 & 89.9 & $\mathbf{B}$ & 11 & 5.9 & 45 & 142 & Hatch & \\
\hline 12 & 101 & $24-6-43$ & 221 & 195 & 88.2 & 26 & 0 & D & 22 & 195 & & \\
\hline 12 & 99 & $24-6-47$ & 139 & 138 & 99.3 & 0 & 1 & 0.7 & 5 & 134 & Hatch & \\
\hline 13 & 170 & $27-8-1$ & 152 & 150 & 98.7 & 2 & o & o & 1 & 150 & Hatcil & \\
\hline 13 & 168 & $27-8-2$ & 122 & 38 & 31.2 & 57 & 27 & 22.1 & 93 & 29 & & \\
\hline 13 & 199 & $27-8-3$ & 388 & 337 & 86.9 & 50 & 1 & 0.3 & 72 & 316 & & \\
\hline 13 & 182 & $27-8-4$ & 508 & 114 & 22.4 & 308 & B6 & 16.9 & 271 & 114 & Scat ${ }^{d}$ & \\
\hline 13 & 174 & $27-8-6$ & 282 & 282 & 0 & 0 & 0 & 0 & 0 & 282 & Hateh & \\
\hline 13 & 168 & $27-8-7$ & 188 & 188 & 100 & 0 & 0 & 0 & 0 & 188 & Hatch & \\
\hline 13 & 192 & $27-8-20$ & 38 & 20 & 52.6 & 14 & 4 & 10.5 & 34 & 4 & Can & \\
\hline 13 & 180 & $27-8-21$ & 315 & 315 & 100 & 0 & 0 & 0 & 315 & D & Scat & \\
\hline 13 & 173 & $27-8-22$ & 249 & 245 & 98.4 & 0 & 4 & 1.6 & 0 & 245 & Hatch & . \\
\hline 13 & 174 & $27-8-23$ & 267 & 245 & 91.8 & 17 & 5 & 1.9 & 7 & 245 & Hatch & \\
\hline 13 & 173 & $27-8-24$ & 249 & 247 & 99.2 & 1 & 1 & 0.4 & 0 & 247 & Hatch & \\
\hline 13 & 166 & $27-8-25$ & 262 & 160 & 61.1 & 45 & 57 & 21.8 & 24 & 150 & & \\
\hline
\end{tabular}

a Can, male eating developing embryos

- Halch, embryos hatched into larvae.

c Aban, male abandoned the brood.

d Scat, broud scatcered in the tube. 
Vable A-4. Experimental data from Neanthes arenaceadentata mated pairs that were exposed to $17 \mathrm{mGy} / \mathrm{h}$ from an external gamaradiation source. The number of days from spawn to hatch and from hatch to spawn as well as the estimated hatch number are provided.

\begin{tabular}{|c|c|c|c|c|c|c|c|c|c|c|c|c|}
\hline $\begin{array}{c}\text { P1 Spawn } \\
\text { to } \\
\text { Fy hatch } \\
\text { (days) }\end{array}$ & $\begin{array}{l}F_{1} \text { Hatch } \\
\text { to } \\
\text { F1 spawn } \\
\text { (days) }\end{array}$ & IO & $\begin{array}{l}\text { Spawn } \\
\text { number }\end{array}$ & $\begin{array}{c}\text { Live } \\
\text { number }\end{array}$ & $\begin{array}{l}\text { live } \\
\text { (z) }\end{array}$ & $\begin{array}{l}\text { Dying } \\
\text { number }\end{array}$ & $\begin{array}{c}\text { Dsad } \\
\text { number }\end{array}$ & $\begin{array}{l}\text { Dead } \\
(x)\end{array}$ & $\begin{array}{c}\text { Abriormal } \\
\text { number }\end{array}$ & $\begin{array}{l}\text { Est. } \\
\text { hatch } \\
\text { number }\end{array}$ & Comments & \\
\hline 9 & 128 & $4-1-8$ & 278 & 0 & 0 & 0 & 278 & 100 & 270 & 0 & $\operatorname{Can}^{a}$ & \\
\hline 9 & 139 & $4-1-14$ & 190 & 98 & 51.6 & 56 & 36 & 19.0 & 183 & 7 & Aban ${ }^{b}$ & \\
\hline 9 & 137 & $4-1-15$ & 74 & 0 & 0 & 6 & 68 & 91.9 & 74 & 0 & Can & \\
\hline 9 & 130 & $4-7-16$ & 190 & 63 & 33.2 & 60 & 67 & 35.3 & 190 & 0 & Can & \\
\hline 9 & 127 & $9-1-17$ & 397 & 87 & 9.1 & 144 & 166 & 43.8 & 315 & 82 & & \\
\hline 9 & 140 & $4-I-2 I$ & 203 & 3 & 1.5 & 130 & 70 & 34.5 & 203 & $\mathbf{0}$ & Scatc & \\
\hline 9 & 131 & $4-1-22$ & 109 & 34 & 31.2 & 28 & 47 & 43.1 & 103 & 6 & Can & \\
\hline 9 & 137 & $4-1-23$ & 74 & 2 & 2.7 & 39 & 33 & 44.6 & 74 & 0 & Can & \\
\hline 9 & 140 & $4-1-33$ & 186 & 38 & 20.4 & 106 & 42 & 22.6 & 186 & 0 & Can & \\
\hline 9 & 120 & $4-1-35$ & 3 & 1 & 33.3 & 1 & 1 & 33.3 & 2 & $\mathbf{1}$ & Can & \\
\hline 15 & 125 & $10-4-2$ & 107 & 82 & 76.6 & 12 & 13 & 12.2 & 67 & 40 & Can & \\
\hline 15 & 133 & $10-4-3$ & 147 & 19 & 12.9 & 23 & 55 & 37.4 & 147 & 0 & Can & \\
\hline 15 & 136 & $10-4-4$ & 109 & 19 & 17.4 & 52 & 38 & 34.9 & 107 & 2 & Scat & \\
\hline 15 & 142 & $10-4-7$ & 132 & 0 & D & 10 & 122 & 92.4 & 132 & 0 & $\operatorname{con}$ & \\
\hline 15 & 121 & $10-4-12$ & 372 & 190 & 51.1 & 50 & 132 & 35.5 & 281 & 91 & Can & \\
\hline 15 & 124 & $10-4-14$ & 261 & 49 & 18.7 & 209 & 3 & 1.2 & 257 & 4 & Srat & \\
\hline 15 & 135 & $10-4-18 a$ & 261 & 7 & 2.7 & 69 & 185 & 70.9 & 260 & 1 & Can & \\
\hline 15 & 139 & $10-4-19$ & 85 & 37 & 43.5 & 27 & 21 & 24.7 & 85 & 0 & Can & \\
\hline 15 & 123 & $10-4-20$ & 523 & 55 & 10.5 & 275 & 253 & 48.4 & 523 & 0 & ian & \\
\hline 15 & $1 ! 6$ & $10-4-31$ & 161 & 138 & 85.7 & 19 & 4 & 2.5 & 44 & 117 & Can & - \\
\hline 15 & 131 & $10-4-32$ & 91 & 6 & 6.6 & 66 & 19 & 20.9 & 91 & 0 & Can & \\
\hline 15 & 125 & $10-4-35$ & 185 & 21 & 11.3 & 73 & 92 & 49.5 & 186 & 0 & Can & \\
\hline 15 & 125 & $10-4-40$ & 349 & 48 & 13.8 & 192 & 109 & 31.2 & 333 & 16 & Can & \\
\hline
\end{tabular}


Tab)e A-4 (cont.)

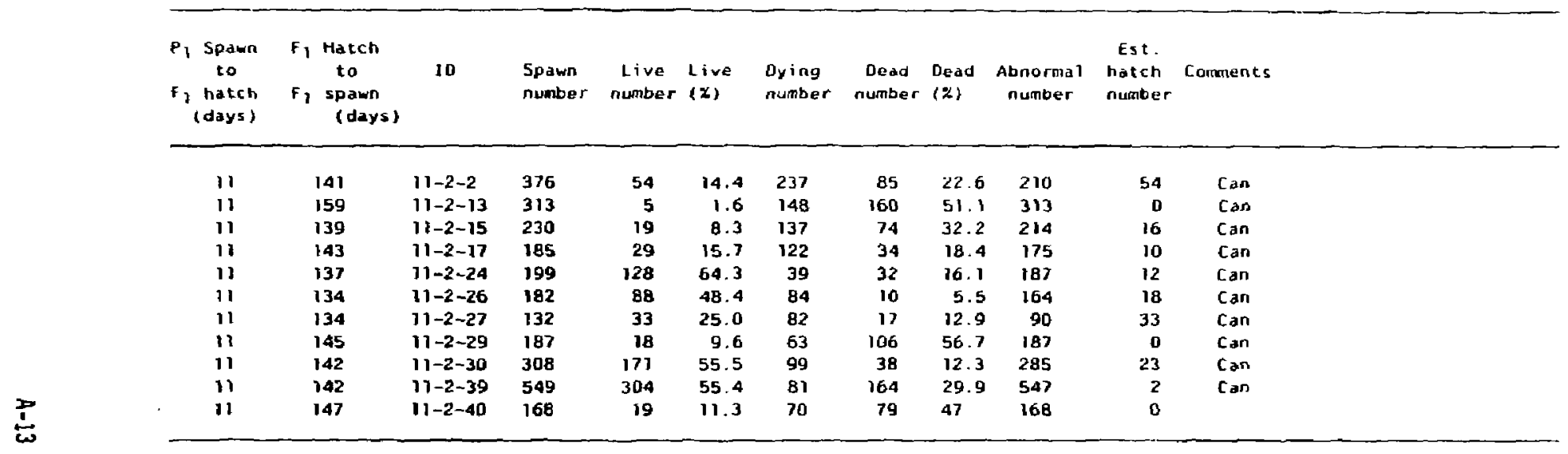

a Can. male eating developing embryas.

b Aban. male abandoned the brood.

c scat. Drood scattered in the tube. 
Table a-A. (cont, )

All of these females resorbed their oocytes and then died.

Io Comments

4-1-2

$4-1-4$

$4-1-7$

4-1-9

$4-18$

$4-1-20$

4-1-26

4-1-27

I 4-1-30

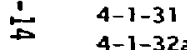

4-1-36

10-4-1

$10-4-8$

10-4-9

10-4- 13

$10-4-22$

$10-4-23$

10-4-30

$10-4-37$

$11-2-3$

$11-2-7$

1] $-2-32$

1)-2-36

$11-2-38$ 